\title{
Covid-19 as an "invisible other" and socio-spatial distancing within a one-metre individual bubble
}

\author{
Annamaria Silvana de Rosa ${ }^{1} \cdot$ Terri Mannarini ${ }^{2}$ \\ Accepted: 5 January 2021 / Published online: 1 February 2021 \\ (c) The Author(s), under exclusive licence to Springer Nature Limited part of Springer Nature 2021
}

\begin{abstract}
Inspired by the social representation theory, the article embraces many aspects of the way in which the space dimension in social distancing has become a central measure for both one's own and others' health protection during the Covid-19 pandemic, evoking symbolic dimensions related to the social representations of "others" that are emotionally driven by fear or mirror the vulnerable self, activating the othering-otherness process. This invisible (sometimes stigmatized) "other"-never previously known - has in a few months infected more than 11 million people on the global scale and caused more than 500 thousands deaths (as of 30 June 2020: https://coronavirus.jhu.edu/). It has dictated where we can go, whether and how we can work, and whom we can meet, induced the virtualization of social relationships ("neighbours from afar" and "together but divided"), and confined working and socio-recreational activities to the home. The socio-spatial prescriptive distancing assumes various meanings in cultural contexts depending on whether lifestyles are more collectivist or individualistic and whether social practices are marked by crowded social proximity or distance. The social representations of cities as complex systems of "places" conceived for social "coexistence" have moved to prescriptive rules of inter-individual spaces ( $1 \mathrm{~m}, 2 \mathrm{~m}$, and even more) for "survival", with significant effects on place identity.
\end{abstract}

Keywords Covid-19 pandemic - Othering-otherness process - Collective memory $\cdot$ Social representations Defamiliarization processes $\cdot$ Socio-spatial distancing $\cdot$ Place identity

\section{Introduction}

Radically and suddenly changing all the aspects of people's lives, the unexpected Covid-19 pandemic, in a few months (from December 2019 to March 2020), became a global phenomenon that has deeply affected the use of public and private spaces as well as having socio-psychological implications. In this article, we will examine some aspects of the "brutal" transformation of social representations and related social practices (Abric 1996; Flament 1994) that have caused discontinuity in lifestyles and the worldwide economy as a turning point in history, marked by "before" and "after"

Annamaria Silvana de Rosa annamaria.derosa@uniroma1.it

1 Department of Social and Developmental Psychology, Faculty of Medicine and Psychology, Sapienza University of Rome, via dei Marsi, 78, 00185 Rome, Italy

2 Department of History, Society and Human Studies, University of Salento, Via di Valesio angolo Viale San Nicola, 73100 Lecce, Italy
(Luhmann 1984). We will offer some examples of and reasons for these transformations, in particular the effect of the introduction of measures for contagion prevention, such as the prescriptive norms of socio-spatial distancing and the virtualization of most working and social activities, which have contributed to redefining the symbolic dimension of private and public spaces as settings for social interaction and multiple functions.

The paper is structured in four main sections:

1. The first section-based on classical contributions from human ethology, cultural studies, anthropology, and environmental psychology-discusses the relevant socio-psychological dimensions of space and distance, focusing on four main concepts: territoriality, proxemics, touching, and public spheres.

2. The second section introduces the perspective of the social representation theory on pandemics, addressing the psychosocial processes of collective memory, anchoring, objectification, and othering in past epidemics and in the Covid-19 outbreak. 
3. The third section focuses on the changes brought about by the Covid-19 crisis in the social representations of places and spaces, both at the cognitive and at the behavioural level. Specifically, this section highlights (a) the emergence of new social practices based on defamiliarization; (b) the emergence of new meanings and uses of places that affect place identity processes; (c) the differentiation of open and closed spaces; (d) the entanglement of places and non-places; and (e) a novel visibility of urban spaces and cities.

4. Finally, the fourth section summarizes the contribution that social science research can offer to policy makers in time of crisis for strengthening community cohesion and reshaping places for social coexistence.

\section{Socio-psychological dimensions of "space" and distance: classical contributions from human ethology, cultural studies, anthropology, and environmental psychology}

Space and time dimensions are so intrinsically related to the life of all species (vegetable, animal, and human) that, in ordinary life, they are often taken for granted as a sort of unreflected common sense nourished by experience, although they have represented pillars of the scientific knowledge in many disciplines from philosophy to physics, biology, ethology, psychiatry, psychology, cultural anthropology, and other social sciences. In ordinary situations, in the contemporary professional work division, we are almost used to considering space as a relevant attribution mainly, and sometimes only, for experts who have to plan, change, or use it (e.g. architects, urban planners, and policy makers). The geometrical conception of space (translated into measures and their connotation: large, narrow, high, low) is not always perceived in its fundamental socio-psychological dimension, except probably in the urban and metropolitan contexts, in which people often suffer due to a lack of space, especially during rush hours, for instance on an over-crowded metro.

\section{Territoriality: the contribution of human ethology}

The notion of territoriality, which is grounded in the study of animal behaviour and has been incorporated into social sciences through the human ethology approach, highlights that control over space is crucial for life, since the control of space grants psychological and physical protection. Different kinds of territories exist (public, home, interactional, and bodily territories, according to Lyman and Scott 2009), which are usually assumed to be taken for granted due to the unreflexive way of learning their functional use as a setting for social practices according to the various roles filled by people at different developmental stages of their life since childhood.

All these spaces/places/territories have been affected by the restrictive measures enforced during the Covid-19 pandemic:

- public territories - namely urban areas with freedom of access-have been interdicted for the majority of people, with limited access accorded only to specific activities or specific categories of people;

- home territories, that is, public territories that are "colonized" and regularly used by specific groups, which develop a sense of intimacy and connection-such as club houses or homosexual bars-have been temporarily banned;

- interactional territories, that is, areas where people can meet and gather, have been reduced to private spaces (households) on the one hand and massively moved into the online non-space on the other hand;

- bodily territories, which refer to the space immediately surrounding the body, thus defining the bubble of privacy and the vital primary space, have been deeply affected by the prescriptions of interpersonal physical distance.

Whether inborn or learned, when some form of territorial encroachment occurs - either violation, invasion, or contamination-a set of prototypical responses can be observed, such as turf defence and insulation. The first one is a violent and aggressive reaction to intruders; it is typically observed in the animal world (Lorenz 1966), but it has been invoked as a natural human response (Ardrey 1996) and as justification for negative attitudes and behaviours towards migrations (Eibl-Eibesfeldt 1970, 1989). Insulation is the use of barriers, either physical or symbolic (including face masks and gloves), to protect the territory against possible invaders.

\section{Proxemics: the study of social and personal space}

Nevertheless, even though a sense of territoriality may be innate, the very way in which we shape our relationship with space is determined culturally and distances are set differently. The anthropologist Edward Hall (1966), in his seminal work on "proxemics", defined it as the "study of the use that individuals make of social and personal space". He noted that the space around people is present as a sort of "bubble" that not everyone can access at will. Unconsciously, people are kept at a distance that varies from time to time depending on the context and the social relationship. There are differences in the distance that two lovers maintain compared with the distance between two people who meet to discuss work 


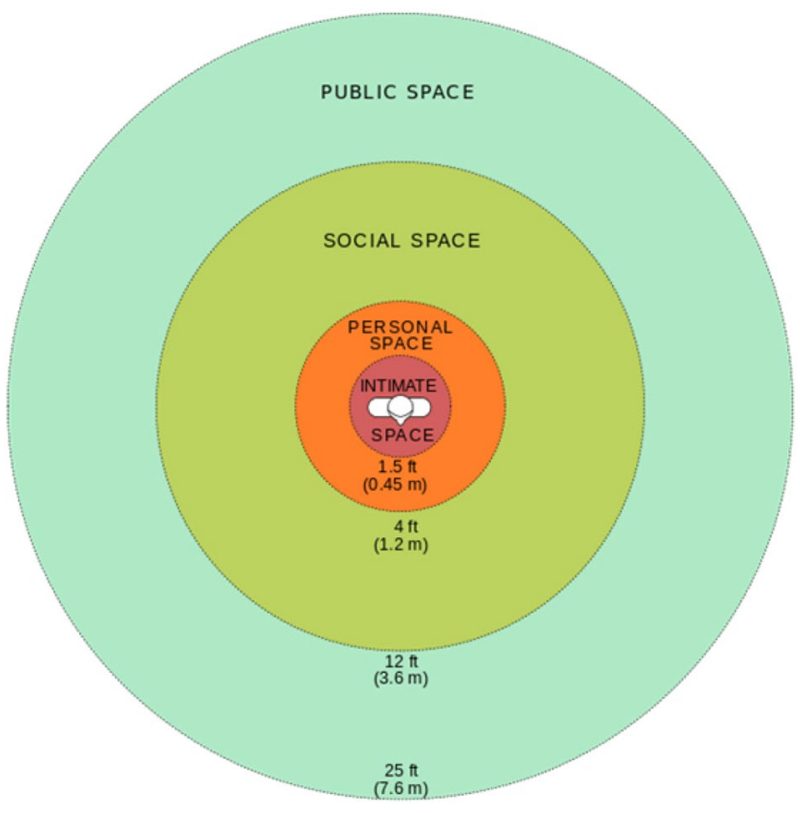

Fig. 1 The four interpersonal distances according to Hall (1966)

or even between two friends and between strangers who are entering into a relationship for the first time.

Hall (1966) divided the space into four interpersonal distances (see Fig. 1). They correspond to the physical distance that people put between themselves and others, which increases the more formal the relationship is ${ }^{1}$.

- Intimate distance (from 0 to $45 \mathrm{~cm}$ approximately). Only those people with whom one has established a relationship of great trust and intimacy can access this space; otherwise, anyone who enters it without consent is perceived as an intruder. Intimate distance is characteristic of close relationships, such as those between partners, between mother and child, and so on. The distance is so small that people can even touch and smell each other through the tactile and olfactory apparatus.

- Personal distance (approximately 45 to $120 \mathrm{~cm}$ ). This space is frequently occupied by those with whom we have familiar relationships. Family members, friends, and colleagues with whom we do not have an intimate relationship but with whom we communicate daily with pleasure and affability can easily access the personal area. At this distance, the most emphasized senses are hearing and sight, while the senses of smell and touch are not fully activated (even though physical contact is within easy reach).

\footnotetext{
${ }^{1}$ Image link: https://upload.wikimedia.org/wikipedia/commons/ thumb/3/35/Personal_Space.svg/610px-Personal_Space.svg.png.
}

- Social distance (approx. 120 to $360 \mathrm{~cm}$ ). Social distance is reserved for formal and impersonal relationships. It is too wide to talk about one's private life or confide in someone but is suitable for dealing with work issues, offering advice, negotiating, and making contracts. At this distance, it is not possible to have physical contact, so only sight and hearing are used.

- Public distance (from about $360 \mathrm{~cm}$ onwards). This space is generally used in public situations, such as a teacher addressing a class or a speaker giving a talk at a conference. Communication is mostly one to many, lacking personal involvement if only supported by visual and partially by auditory apparatus.

Although this classic contribution still has didactic clarity (in particular regarding the distinction between the intimate and the public distance), in the light of cultural psychology and anthropology, the socio-cultural components may be considered transversal to all the spheres and even the geometry as the metric of four interpersonal distances designed by Hall may vary according to different cultures.

\section{"Touching": the contribution of anatomical, anthropological, and psychological disciplines}

Edward Hall (1966) differentiated cultures as contact and non-contact, each characterized by different interpersonal and social distances. Compared with Northern European and North American cultures, Mediterranean cultures are more prone to engaging in closer interactions, touch, and eye contact as well as being more tolerant of crowded spaces.

In his inspiring book Touching: The Human Significance of the Skin (1971), Ashley Montagu, Professor of Anatomy and of Anthropology at New York and Harvard universities, started with the assumption that touch is the most important sense associated with skin - as demonstrated by many discoveries made by physiologists, anatomists, neurologists, psychiatrists, psychologists, and so on-and is the first to be developed when the embryo is two centimetres long and less than eight weeks old. Then he examined the national and cultural differences in tactility, which occupies people's whole life from their primary experiences as a foetus and in very early childhood until adulthood. Tactility ranges from the absolute lack of contact in the high-class Puritan AngloSaxon culture (which usually entrusted babies to nurses for breastfeeding and then institutionalized them for their education away from home) to the full expression and social need for physical contact among neo-Latin and primitive peoples (just think of the tactile communication practices between Eskimo Netsilik mothers and children carried on their backs) but also in the Japanese culture. 
Evidently there are peoples who have easy contact and others who do not and the Anglo-Saxons are among the latter. In the behaviour of people belonging to cultures of this type in certain circumstances, curious ways of expressing non-tactility can be observed. For example, when an Anglo-Saxon shakes hands he seems to invite the other person to keep the right distance. And this also happens in a crowd. In a crowded metropolitan carriage, the Anglo-Saxon remains rigid and reserved with an empty expression on his face that seems to deny the existence of the other passengers. The contrast is very vivid with the French underground. Here the passengers lean against each other, fully relaxed, at least without feeling the need to ignore each other and apologize to the person they lean against or push against. Often the fact of leaning or staggering is an occasion for a good laugh or a joke, and nothing is done to avoid looking at the other passengers. While waiting for a bus the Americans keep each other at a distance, like swallows on a telephone line, unlike the Mediterraneans who push and crowd (Montagu 1971, ed. 1975, pp. 243-244).

Regarding individual differences and the possibility that, after half a century, the above-mentioned differences are simply objectified in national or regional stereotypes or still based on anthropological observations, more recent studies have shown that-despite globalization and the intensification of international exchanges that, due to massive online communication and travelling experiences, may have induced some sort of homologation in social and interpersonal behaviour-cultural differences still exist. For example, quoting several studies in line with the classical contributions of Bogardus (1933) on social distance between two or more social groups, two researchers in cognitive and information sciences at the University of California, Justin L. Matthews and Matlock (2011, p. 185), stated that:

... individuals in some racial groups may be reluctant to interact with individuals in other racial groups. African-Americans tend to feel close to other AfricanAmericans, but far from people of Asian or European ancestry (Hoxter and Lester 1995). People of Southeast Asian descent (e.g., Laotian, Vietnamese) feel close to members of their own group, but desire close ties with Caucasians (Lee et al. 2002). Social distance can also influence decisions made by social groups, including choices related to selection of educational attainment (Akerlof 1997) and even the ease with which people learn a second language (Schumann 1976). It may also refer to the strategic use of language to create distance to exhibit power or control (Shepard et al. 2001), and it can be used to make others feel excluded (Riggins 1997). Social distance can also refer to physical dis- tance between individuals while they are interacting (Hall 1966). It can also influence how people reason about space. In one study, Americans with negative attitudes toward Mexicans estimated that Mexican cities were farther south than they actually are, and Americans with negative attitudes toward Canadians estimated that Canadian cities were farther north than they actually are (see Kerkman et al. 2004).

Crowding and density are two more concepts that we can use to investigate how the pandemic has changed the use of space and which psychosocial responses these changes have elicited. Though connected, density and crowding are distinct concepts: density is the ratio between the physical space and the number of persons within it, while crowding is the feeling of a lack of control over the physical space around us. When the density is high, people may feel distressed because their primary space is violated, their privacy is invaded, and their movement is restricted. However, this is not a mechanical and universal psychological response: density only sets the minimal condition for the crowding experience. Such a subjective experience may occur either because individuals feel overwhelmed by the presence of others or because the social density interferes with their activities (Stokols 1972).

\section{Public spheres: cultural approaches to socio-spatial prescriptive distancing}

Communal life takes place in public spheres, that is, open spaces that provide individuals and groups with both the material and the immaterial infrastructure that they need to accomplish their goals, carry out their activities, and fulfil their multiple needs. Three different intertwined dimensions shape public spheres (Jovchelovitch and Priego-Hernandez 2015). Two of them - the political and the psychosocial aspect — stand on the immaterial side: they constitute the arenas for public debate and public opinion, in which civil society develops its judgements and opinions. They are also the relational and symbolic arenas of social behaviour, in which communication, representation, and sense-making processes occur and individuals and groups interact. However, public spheres also have a material quality, which is represented by the physical environments, either natural or built, in which the political and psychosocial sides of communal life mostly take place: typically, though not exclusively, in cities and neighbourhoods where people gather, communicate and debate, interact, think, and feel in everyday life. The three dimensions are entangled as culture-which can be deemed as a precipitate of the social processes that occur in the political and psychosocial dimensions-determines the norms ruling the use of space and distances (Allcott et al 


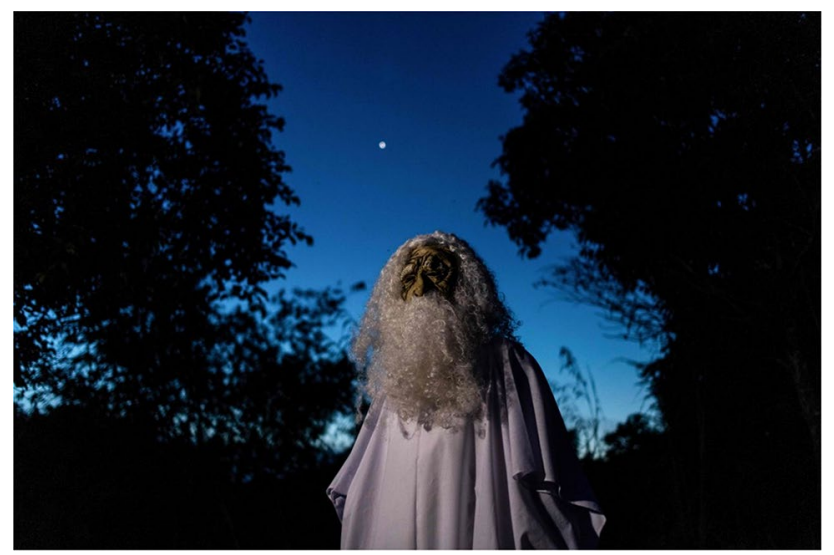

Fig. 2 Use of a ghost in a rural area of Malaysia as a scaring tactic to regulate social distancing behaviour

2020; Phillips 2020). Such norms vary greatly across different cultural contexts.

By taking into account the cultural relevance in shaping the psychological perception of the "space" and its social use in terms of socio-spatial distancing habits in different cultural contexts, it is also very important to consider the impact of such prescriptive norms as health and safety prevention measures in terms of both the cultural symbolic system and the social class inequalities. It is enough to consider, among other examples, that it may be difficult

- to apply socio-distancing rules in crowded markets, in massive religious collective rituals, or at mass gatherings, big concerts, or entertainment spectacles, at cinemas, shopping malls, and museums (see among others the study conducted by Yezli and Khan (2020) in the Kingdom of Saudi Arabia), or in close socio-recreational settings, like pubs or discos, gyms, and swimming pools;

- to wash one's hands continuously in countries where water or hygienic services are not easily accessible, such as in some areas in poor countries, in refugee camps, or for homeless people in any part of the world (even in the most prominent economies), for whom buying hand sanitizers is a privilege;

- to apply massive serologic texts and swabs or to expect all citizens to download apps for contact tracing with those who have fallen ill and asymptomatic carriers of Covid-19 in areas still dominated by magic culture, for instance some rural parts of Malaysia/Indonesia, where "ghosts" are still used as a "scaring tactic" to regulate social distancing behaviour (see Fig. 2). However, magical beliefs are not exclusive ways of thinking to primitive or archaic cultures, as has been demonstrated empirically by the research on social representations of madness and mental illness undertaken in multiple contexts in urban and rural areas in different European countries and in Brazil (de Rosa 1987; de Rosa and Bocci 2013; de Rosa and Schurmans 1990). These studies showed the coexistence of myths, science, and social representations, even in advanced Western societies, in contrast to the linear model of science as a progressive system of knowledge that fully replaces common sense and myths (de Rosa 2009, 2010). The results of these studies empirically proved the theoretical construct of "cognitive polyphasia", defined by Moscovici (2000, p. 245) as "our tendency to employ diverse and even opposite ways of thinking-such as scientific and religious, metaphorical and logic, and so on - as a normal state of affairs in ordinary life and in communication". According to Paez and Perez (2020), "as a possible example of polyphasia, it can be hypothesized that people who seek greater scientific knowledge also seek and use more knowledge and magic practices in the face of the Crown Virus"; ${ }^{2}$

- to apply socio-spatial distancing even with relatives in the same house, depending on the socio-centric housing models (like crowded condominiums) or individualfamily-centred models (uni-family villas);

One powerful explanation of the unequal impact of the virus relates to the resources available to the "haves" and the "have-nots" (Tomazin 2020). For example, those on lower wages are less likely to engage in physical distancing, for the simple reason that they are unlikely to be able to work from home and unable to avoid crowded public transport when getting to work (Ogbunu 2020). Indeed, location data from 15 million U.S. phone users revealed that limiting movement was a luxury low-income people were less likely to be able to afford. While everyone moved around less once physical distancing measures were introduced, wealthier people were more likely to stay at home sooner and more often. This effect was most pronounced during the work week, which suggests that this difference was due primarily to the fact that people with higher incomes tended to have greater flexibility to work from home. More affluent people had a physical distancing "head start"-reducing their exposure to the virus at a crucial point in time and hence diminishing their risk of falling ill (Valentino-De Vries et al. 2020) (Jetten 2020, p. 21).

- to cope with social isolation in the lockdown phase, dealing with individual, inter-group, generational, and cultural differences in the abilities to activate coping and resilience strategies to manage social isolation and connection (Bentley et al. 2020).

\footnotetext{
2 Source: https://www.thestar.com.my/news/nation/2020/04/17/ghost
} ly-goings-on-malaysian-phantom-on-lockdown-patrol. Image link. 
In the absence of a vaccine, one of the most vital strategies for slowing the pandemic is social distancing. However, distancing clashes with the deep-seated human instinct to connect with others. Social connection helps people regulate emotions, cope with stress and remain resilient during difficult times. By contrast, loneliness and social isolation worsen the burden of stress and often produce deleterious effects on mental, cardiovascular and immune health. Older adults, who are at the greatest risk of severe symptoms from COVID-19, are also highly susceptible to isolation. Distancing threatens to aggravate feelings of loneliness and could produce negative long-term health consequences. Scholars have identified strategies that could mitigate these outcomes. First, in psychological terms, loneliness is construed as the subjective state that one is not experiencing enough social connection, whereas isolation is an objective lack of social interactions (Van Bavel et al. 2020).

\section{Pandemics through the lens of social representation theory}

According to the social representation theory (de Rosa 2013a, 2016, 2019; de Rosa et al. 2018a, b; Emiliani and Palmonari 2019; Jodelet 2008, 2016; Lo Monaco et al. 2016; Moscovici 1961/76, 1988, 2000, 2001; Sammut et al. 2015), there are many aspects in which the space dimension has become a central measure for both one's own and others' health protection during the Covid-19 pandemic, evoking symbolic dimensions rooted in the collective memory related to social representations of "others" that are emotionally driven by fear or mirror the vulnerable self, activating the othering-otherness process (de Rosa and Mannarini 2020; Mannarini et al. 2020).

From a global perspective, by extending our analysis of Covid-19-related discourses from different sources (national, international and local press, press agencies, news channels, institutional website/documents, and social media networks) to ten countries from five geo-cultural contexts (Europe, North-America, Latin America, Asia and Africa), we found-among other results- that

Outgroup blaming and stigmatization occurred almost everywhere, with different and multiple targets depending on the context: in the early phase external and diverse groups were targeted, such as the Chinese people, irregular immigrants, foreign travellers bringing the virus "home", and then, as it became clear that everyone could be infected and infect others, closer groups were blamed and considered responsible for the contagion (e.g., infected people, rich people).
The racialization of the virus as "Chinese" as well as "White European" (as in the South African case: Sitto and Lubinga 2020) or personified as "the invader immigrants" (...) witnessed how the othering process is ubiquitous and can be reversed according to different cultural and socio-geo-political positioning. At the very beginning the Coronavirus has played the role of catalyst of racism, deviating media attention from the traditional targets of prejudice (immigrants, blacks, Asians, ...) to the "new invisible other". Howeveralmost everywhere - and especially in the countries where the fear for the stranger has continued to be exploited by sovereignist leaders for personal strategic power goals in exchange for citizen protection from risks - the two media targets (i.e., the new unknown stranger COVID-19 and the well-known outgroups) have been associated, often denying the first one to re-focus attention on the traditional targets of fear and hate (de Rosa, Mannarini et al., in press).

\section{Collective memory: the dynamics of remembering/ forgetting/denying}

According to Moscovici (2000, p. 54), "Experiences and memories are neither inert nor dead. They are dynamic and immortal. Anchoring and objectification are therefore ways of handling memory". Anchoring has been found to evoke the collective memory of historical epidemics, as objectified in the history of pandemic infographic (Fig. 3) and narrated in the literature; among the most famous are the following:

(a) The "plague" that hit the city-state of Athens in 430 B.C. It was narrated by the famous Greek historian Thucydides and by the Roman Lucrezio, who lived in the first century B.C., in his De Rerum Natura, in which he described the plague that struck Athens as "a deadly disease and flow that scattered the fields with corpses, devastated the streets and emptied the city of inhabitants";

(b) Justinian's pandemic of bubonic plague that struck the Byzantine Empire - and, above all, its capital Constantinople, killing $40 \%$ of its population-between 541 and 542 A.D., as narrated by the Byzantine historian Procopio, with serious consequences for the Gothic war (535-553 A.D.), allowing the Ostrogoths to occupy the Italian peninsula and leaving Rome almost without inhabitants for a few months in 546 A.D.;

(c) The Black Death plague, which arrived in Italy around 1348 and soon spread to every corner of Europe, killing at least a third of the population and being eradicated only in 1353. It was narrated in the Decameron by Boccaccio, an eyewitness to the spread of the disease, which he called a "deadly pestilence". The Florentine 


\section{HISTORY OF PANDEMICS}

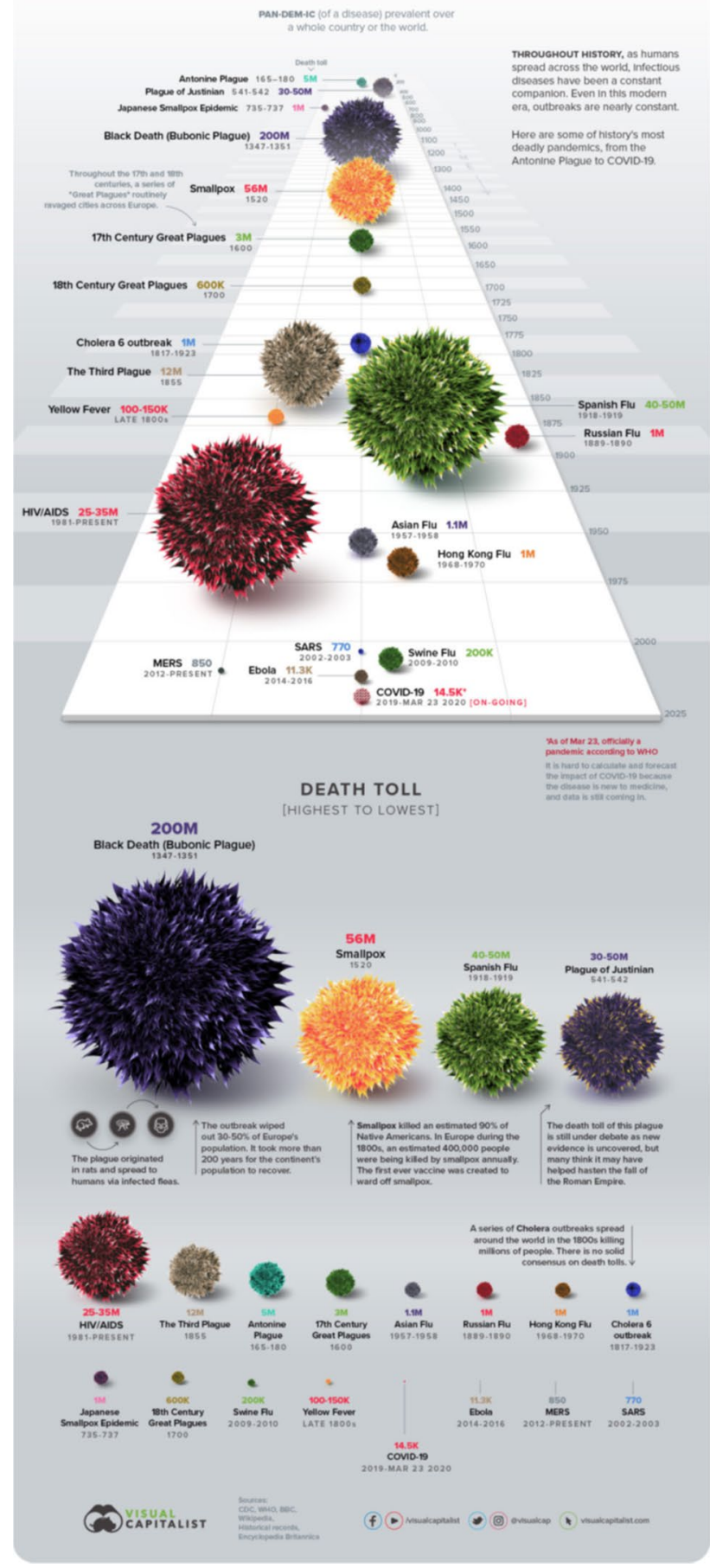

Fig. 3 History of pandemics infographic

poet told the story of ten young people who left Florence for ten days in the hope of escaping the contagion. To entertain themselves, they decided to tell, in turn, ten stories every day, pre-establishing a theme to follow: this was a desperate attempt to keep intact the world in which the young people had lived until then, which the plague was sweeping away with surprising violence $^{3}$;

(d) The bubonic plague of 1630, narrated by Alessandro Manzoni in Promessi Sposi, causing about one million deaths and devastating, among others, the same cities, like Milan, Bergamo, and Como, that were most affected by Covid- 19 in $2020^{4}$;

(e) In the last century, the plague narrated by Albert Camus in 1947, close to the end of the Second World War, representing the epidemic disease as the symbolic representation of Evil and at the same time a lesson of meaning, placed in solidarity and in the human struggle against historical inauspicious events. These are repeated, although in different forms: a local epidemic of the plague in Oran, Algeria; the global pandemic of Covid- 19 in $2020^{5}$; or the epidemic narrated by Gabriel García Márquez in 1985 in Love in the Time of Cholera, set between the late 1800s and the early 1900s, in Colombia. ${ }^{6}$

Anchoring processes connect the present to the past, ${ }^{7}$ but they also pave the way to the future. We still cannot tell what the social representations of the Covid-19 pandemic will be in the collective memory and whether they will have a significant role in the history and the identity of the communities that have been most affected and that have suffered the most. Even if the magnitude of this pandemic is huge and its effects devastating on multiple levels, the odds that such a tragedy could fall into oblivion cannot be zeroed. We have astonishing evidence of how a catastrophe, such as the Spanish flu, which caused an impressive number of casualties in

\footnotetext{
${ }^{3}$ See: Michelangeli, B. (20 March 2020) 'Le pandemie più famose della storia, raccontate dalla letteratura', Il Faro Quotidiano telematico del Mediterraneo,; https://www.ilfaroonline.it/2020/03/30/lepandemie-piu-famose-della-storia-raccontate-dalla-letteratura/32637 1/ accessed May 20.

${ }^{4}$ See: Mercadante, F. (March 12) COVID-19, il Nord come ai tempi della peste del 1630, Il sole 24 ore, Accessed at: https://www.econo poly.ilsole24ore.com/2020/03/12/covid-19-peste-nord/?refresh_ce=1 accessed May 20.

5 See: interview to Prof. Pierangela Adinolfi, University of Turin, 14 April 2020) Rileggere "La Peste" di Albert Camus ai tempi del Coronavirus Interview University of Turin News; https://www.unitonews. it/index.php/it/news_detail/rileggere-la-peste-di-albert-camus-aitempi-del-coronavirus accessed May 20.

${ }^{6}$ See: Rizzi \& Kumar, March 19,2020) even offered in streaming on March 20 from 18 alle 24 on the channel YouTube of the Nidodiragno Produzioni ((https://www.riviera24.it/2020/03/amore -ai-tempi-del-colera-in-streaming-619733/ and https://www.youtu be.com/channel/UCAY4vgX4YnMpVPN2a-qP80w?view_as=subsc riber\&fbclid=IwAR00MP-Xm2m6Mz5M9jZSU5ka0fwHIuk4ptPhs Z0eqWm9UpMOtNt44smUiFo) accessed May 20.

7 Source: https://www.visualcapitalist.com/history-of-pandemics-deadl iest/ accessed May 20.
} 
many countries, has been removed from the public sphere as a result of a set of socio-cognitive and emotional factors that confined it in the private memory of families (Lima and Sobral 2020).

Compliance with health prevention restrictions dealing with widely shared social practices inscribed in the collective memory (Jodelet 2011) has not been evident, and it is still not easy given that "the transformation of social memory often requires a deliberate act, because there is inertia to our embodied social practices, which function largely without reflexivity" (Wagoner 2015, p. 152).

\section{The processes of anchoring, objectification, and "othering"}

Anchoring and objectification are the two basic processes through which social representations develop. Anchoring, which is a way to make sense of unfamiliar events through a connection to past familiar experiences and objects, is detectable in the public understanding of almost all the most recent infectious diseases (AIDS, Ebola, SARS, avian flu, and mad cow disease: Idoiaga et al. 2017; Joffe and Haarhoff 2002). When Covid-19 started to spread, the media and even some scientists compared the new virus to "common flu" (Paez and Perez 2020), just as had happened with mad cow disease when it first appeared (Washer 2006). Anchors serve the primary function of familiarization, and the initial reference of public discourse to a harmless infection such as flu was aimed at minimizing the threatening nature of the virus and reassuring people. Paradoxically, in the Covid-19 pandemic, familiarization with the threatening object resulted in the prescription of defamiliarization practices: above all, the equation between physical distancing and care for others (de Rosa and Mannarini forthcoming).

Objectification is the process through which abstract concepts are given concreteness, so they become understandable and close to people's experience. In the case of invisible threats, such as viruses, objectification works by making them visible and tangible, for instance by associating them with a colour, a nation, or a group: that is, by anthropomorphizing them. Racialization, for instance, clearly operated in the definition of Covid-19 as the "Chinese virus". These socio-cognitive and communicative strategies result in the categorization, identification, and differentiation of self and others, substantiating the othering process. Representations of otherness are the key to identity since they provide the basis for building a sense of who we are and who we are not. However, they also bring about a tendency to overestimate the collective self and devalue other collectives, along with a radical simplification of the complexity of life, which is reduced to a few basic dichotomies: us and them, good and bad, and friend and enemy (de Rosa et al. 2020a, b; de Rosa and Mannarini 2020; de Rosa, Mannarini et al., in press; Mannarini et al. 2020; Salvatore 2018).

\section{The Covid-19 pandemic: the virus as "invisible other" and the psychology of socio-spatial distancing}

Classical contributions on stigmatized "others", like mentally ill persons and madmen, have been inspired by the social representation theory following different paradigmatic approaches. Adopting a socio-anthropological approach, Denise Jodelet (1989/1991) conducted a field study about social representations and practices towards mentally ill people by the host community in a village in central France, where mental patients have been fostered out to families since 1900. This study is exemplary in terms of socio-spatial distancing used as a practice drawn in the collective memory of the host community and transmitted between generations to situate otherness. The separate use of places and objects objectifies the exclusion of the mentally ill: the archaic fear of mental illness nourished the magical fear of symbolic contagion through body contact, justifying practices of social distancing and habits in housing these "others" (like washing dishes and clothes separately, locking them out of the family living spaces and activities, such as having dinner, watching television, or playing with children, using different entrances to enter/leave the house, etc.).

Adopting the "modelling approach" to social representation (de Rosa 2013a, 2014), developed to equate the complexity of the methods and techniques using multi-channel communicative tools (verbal, textual, figurative, etc.) to the complexity of interrelated theoretical constructs shaping social representations (attitudes, beliefs, common sense, stereotypes, identities, collective memory, etc.), the multiyear research programme conducted by de Rosa in different cultural contexts by using drawings, free associations, social distance scales, free interviews, and questionnaires (as well as historical textual and artistic sources for exploring the links with the collective memory) detected imaginary dimensions of magic-phantastic, criminalized, medicalized, and psychologized social representations of madness and mental illness, leading to the regulation of social distance from the mad person in different contexts, as the results of the social distance scale ("if you meet a madman in the street ..." show (de Rosa 1987, 1995; de Rosa and Bocci 2013).

Like the invisible madness-which scares ordinary people and children, who feel free to express the fear of physical contagion clearly at 5-8 years old ("If I touch him, I too become mad!") and that of psychological contagion following adolescence ("If I imitate his behaviour, I too become mad!")—-the invisible virus Covid-19, never previously known, has been perceived as the racialized "other" in all the countries where it landed. Socio-spatial distancing-before 
becoming a safety rule prescribed by governments to protect citizens' own and others' health within a one- to two-metre droplet bubble - has been a psychological measure anchored in the collective memory to avoid contagion from the infectious other (widely identified as "disgusting Chinese"), nourished by conspiracy theories not only among ordinary lay people but even among top political leaders in the name of the sovereign ideology.

However, the virus has changed the way in which we look at ourselves and others in many ways, and it has changed our relationship with the world and our sense of what we value in it. Depending on our own system of social representations as interrelated dimensions of differently shared values, attitudes, emotions, social practices, stereotypes, prejudices, and even stigma, the process of "othering" activated by the fear of virus contagion may also stimulate the inclusive process between $m e, u s$, and other, reinforcing the sense of belonging to a supra-ordered category of humanity as one community, stimulating solidarity, mutual support, and concern for "all of us travelling through life in the same boat".

Fundamentally, what we see here is that COVID-19 has changed our notions of "self" and associated calculations of "interest", so that these are more inclusive of others. More particularly, whether we define ourselves as "us", and if so, who is included in that definition, becomes critical to our social and healthrelated behaviour (Jetten 2020, pp. 20-21).

\section{Changes in the social representations of "spaces" and "places" during the Covid-19 outbreak}

Collective memory is not only carried in bodies, language and text, but also in space/place (...) Social representation theory conceptualizes the environment as being constructed (in both the symbolic and material sense) by social groups embedded within a cultural tradition. In relation to collective remembering, we can say that a group's memories become objectified in the environment (Wagoner 2015, p. 154).

The tiny Covid-19 virus, never seen in human beings before, has not only infected more than 11 million people across the world and caused more than 500 thousand deaths (as of 30 June 2020; https://coronavirus.jhu.edu/) "but it has dictated where we can go, whether we can work, and who we can meet". ${ }^{8}$ During the pandemic emergency, people

\footnotetext{
8 Thompson, G. (2020) Editorial, Mental Health during the Covid19 Pandemic, Special Issues, You need resilience to overcome the mental health crisis of COVID-19, Newsletter of the International Network for Personal Meaning; https://www.meaning.ca/meaningful
}

experienced all forms of territorial encroachment-violation, invasion, or contamination. We will offer some examples of all three occurrences. In the most serious phases of the outbreak of Covid-19, people were confined at home for quite long periods of time and were even forced to share their domestic spaces with their family as a new work or school setting. Depending on the magnitude and physical organization of the household and on the number of people living in it, many individuals may have experienced crowding as a result of the prolonged and repeated violation of their privacy and primary space or limitations in their activities. In conflicting or violent relationships, these conditions, as well as the forced physical proximity to abusive partners, may have escalated aggressive behaviours. Indeed, in the first three months of confinement, domestic aggression and femicide increased by $20 \%$ in all the United Nations member states. ${ }^{9}$

Occurrences of people gathering together (or crowding) in public territories have technically constituted an invasion of personal space, with such behaviour being perceived by many citizens as showing a lack of respect for safe interpersonal distances. The unwarranted use of public spaces has constituted a violation, as in the recurrent episodes of people, especially young people, meeting in the street for aperitifs or the so-called "movida" (nightlife) ${ }^{10}$ on the streets or in the squares, socially recognized as being inspired by genius loci ${ }^{11}$ or anima loci (Hilman 2004). These episodes initiated a harsh debate on the opportunity to lift restrictions. Finally, contamination (or fear of contamination) occurred as a result of the pollution of the space surrounding the bodily territory, pollution that was constantly managed through the rituals of washing hands, sanitizing objects, wearing masks, and keeping a distance.

Social distancing and the interdiction of public territories also impeded one of the four main responses to collective trauma, that is, crowd gatherings. When a collective trauma occurs, people usually respond by searching for information,

Footnote 8 (continued)

-living-project/positive-living-newsletters/; https://mailchi.mp/95f6f 6e3d3e2/pldt-april-1232095, accessed 24 April 2020.

9 Source: La Repubblica (4 May 2020): https://www.repubblica .it/esteri/2020/05/04/news/donne_aumento_violenza_coronavirus_ mondo-255650898/.

10 Source: Il Fatto Quotidiano (8 May 2020): https://www.ilfattoquo tidiano.it/2020/05/08/coronavirus-polemiche-per-i-navigli-affollatiultimatum-di-sala-o-si-cambia-o-li-chiudo-galli-la-situazione-a-milan o-e-una-bomba/5795259/. See also D'Urso (2020).

11 Ordine degli Psicologi del Lazio (2020) 'Genius Loci e assembramenti in città' Festival Psicologia, https://festivalpsicologia.it/argom enti/genius-loci-assembramenti, accessed 1 June 2020. Ordine degli Psicologi del Lazio (2020) Il corpo che manca, Festival Psicologia, https://festivalpsicologia.it/argomenti/coronavirus-assenza-corpo, accessed 17 April 2020. 
Fig. 4 A lady embracing a monument as an expression of love (Source Townshend, in press)

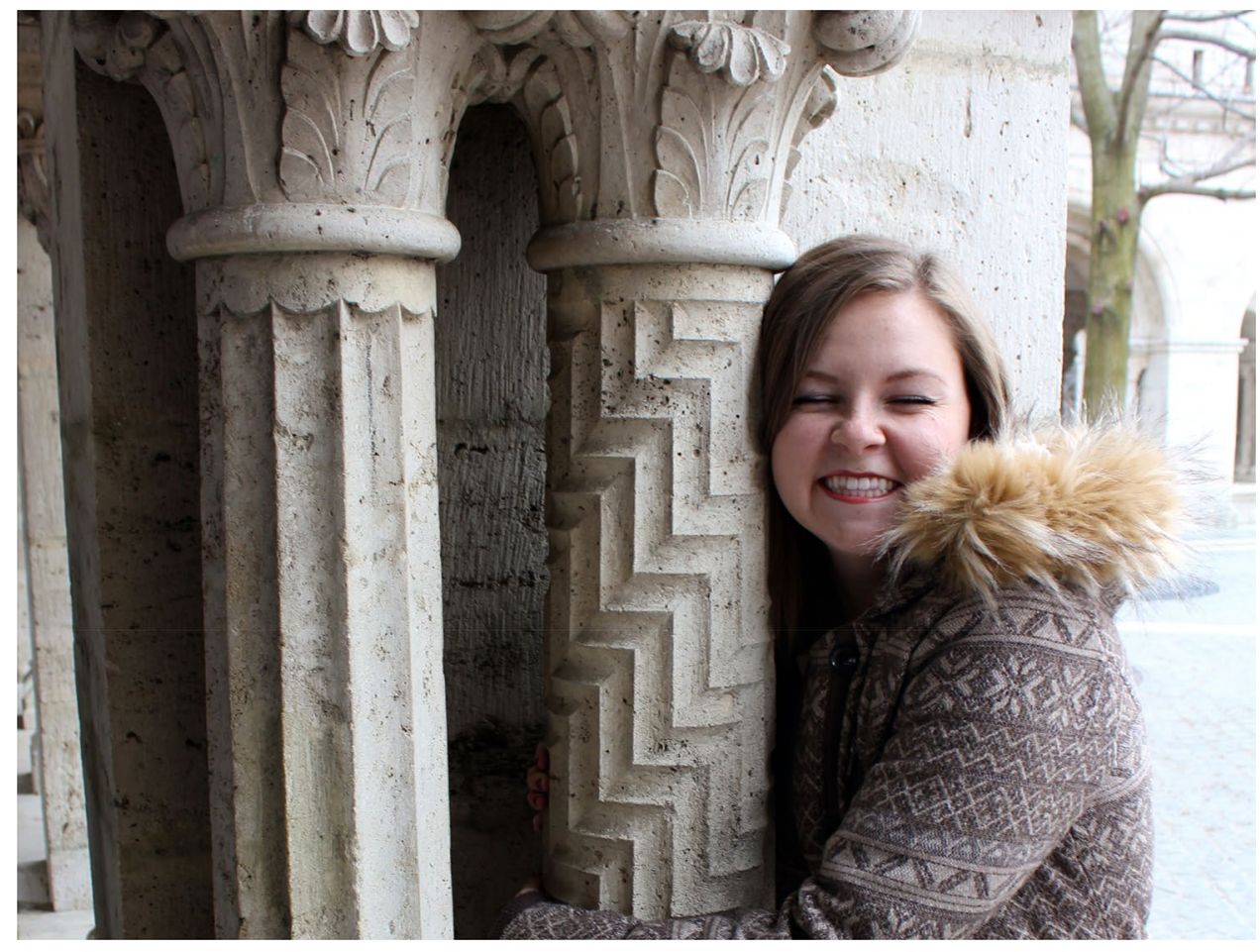

talking to each other to share their feelings and concerns, helping others (directly or indirectly), and gathering in public spaces (Rimé 2020). Specifically, gatherings allow the personal and private experiences and feelings of individuals to be shared, to become public, and to turn into collective symbolic acts, which are likely to maintain great salience in the collective memory. The changed "spaces" and "places" dictated by Covid-19 have deprived people of this option.

\section{The defamiliarization of the spatial- emotional closeness relationship}

Covid-19 has not only dictated where we can go, whether and how we can work, and whom we can meet and at what distance but has also induced the virtualization of social relationships ("neighbours from afar" and "together but divided") and of working and socio-recreational activities confined to the home (smart working, virtual museum tours, at-home concerts, biking at home, etc.).

The fast redefinition of the functional use of spaces and places imposed by the lockdown measures (some of them, like smart and flexible working, even as an irreversible or at least long-term prospect beyond the lockdown phase) has widely generated a psychological impact on common sense and social practices, producing controversial social representations facing the defamiliarization of the relationship between spatial and emotional closeness through paradoxical semantic antinomies, like "spatial distancing-affective proximity", "close from afar", and "together but divided". Such antinomies are counter-intuitive with respect to the symbolic systems learned in any culture and species, in which love means general proximity and closeness, as we have seen in the notes on human ethology (paragraph 1.1), proxemics (paragraph 1.2), and "touching" (paragraph 1.3), although with some differences between the four dimensions of distance (intimate, personal, social, and public) depending on specific cultural contexts.

Humans are not the exclusive targets of the symbolic and emotional assimilation of love-proximity and closeness, and the new prescriptive rules adopted during the Covid19 pandemic have obliged people to defamiliarize the spatial-emotional closeness relationship through paradoxical semantic antinomies (with the interdiction for example of visiting elderly relatives, that is, fathers and mothers or grandfathers and grandmothers, as they are the most vulnerable people, to avoid potential contagion from asymptomatic family members). The well-experienced emotional assimilation of love-proximity and closeness may even be directed to immaterial targets, like monuments inspiring the sense of beauty as an essential spiritual need for sensible people (see Fig. 4).

The need for awareness of the defamiliarization process involved in the new representation of spatial and physical distancing - as an act of care towards other group members, not as a sign of mistrust, and even towards the vulnerable members belonging to one's own family - has relevant consequences for spreading correct information campaigns that, on the one side, prevent the risk attitude implicit in the safety 
perception related to the identity belonging to one's own ingroup and, on the other side, prevent stigma and prejudices driven by the "othering" process, associated with the social representation of Covid-19 as the racialized infectious other.

In a COVID-19 context, these various processes can have ironic effects. Because distrust and disgust are lower for in-group than out-group members, people might be more likely to engage in behaviours that risk disease transmission specifically when interacting with people who they perceive to be in-group members. It has been clear from the beginning of the COVID-19 outbreak that most transmission occurs within the context of families or other communal gatherings (e.g., birthday parties; weddings), rather than through contact with strangers or foreigners (Cha, 2020). For this reason, "othering" the disease, as a problem caused or experienced by out-groups (see also Chapters 7 and 19) misrepresents who the most likely vectors arethose with whom we feel safe. This also leads us to take risks that we otherwise would not. (...).

Public health messaging needs to take account of these social identity dynamics. In particular, it needs to engage with the fact that people's desire to keep ingroup members safe is at odds with the fact that they are slow to recognise the risks that in-group members pose to health. A key way to do this is by emphasising that physical distance is an act of care towards other group members, not a sign of mistrust (Cruwys 2020, p. 72).

\section{New meanings and uses of public and private places}

\section{Place identity}

Places and place identity are core issues in a review of the wide literature in socio-psychological sciences (de Rosa 2013b) that has identified environmental applied social psychology as a multi-perspective disciplinary field at the intersection of pluri-paradigmatic contributions from social psychology, community psychology, environmental psychology, the psychology of tourism, applied social psychology, and health psychology (Fig. 5) but that could be extended to other fields, like economic psychology, advertising and communication, marketing, and others. Of course, an even wider collaborative scenario of networked fields of knowledge might include other social sciences (like semiotics, anthropology, ethnography, urban and rural sociology, political sciences, etc.), human disciplines (history, art, etc.), and domains such as urban planning, architecture, civil engineering, informatics, and technology applied to the protection of the urban and natural ecosystems.

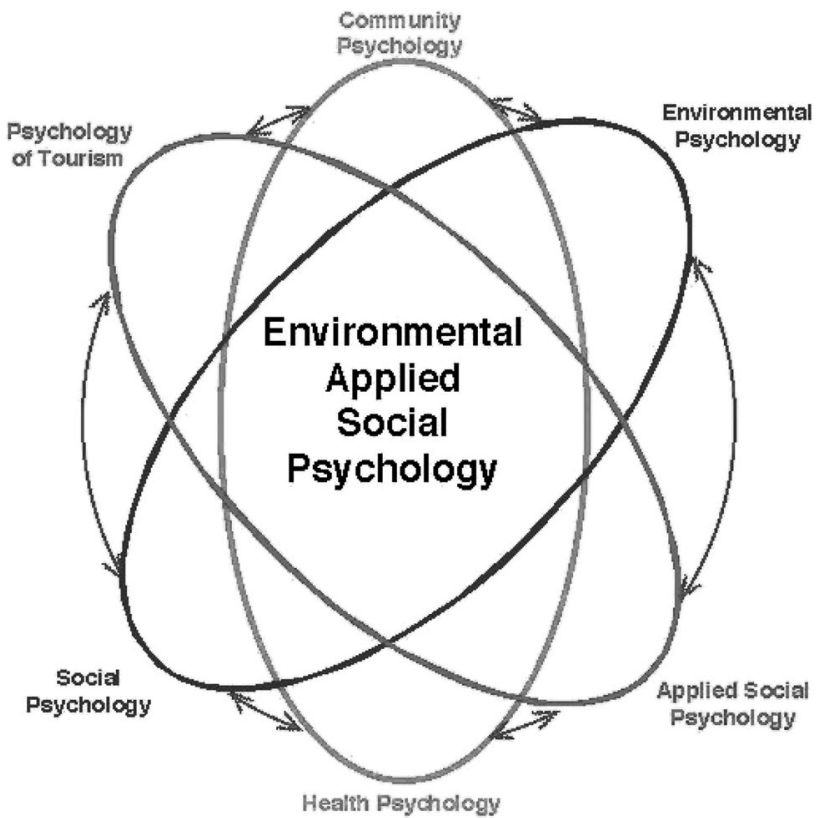

Fig. 5 Environmental applied social psychology as a multi-perspective disciplinary space (de Rosa 2013b, p. 323)

"Places" and "spaces" share the spatial dimension, but, besides this and contrary to a reductionist view as being simply physical or functional settings, places are charged with symbolic meanings and emotional connotations both in private and in collective spheres, in some cases becoming an integral part of self-, social, and even national or supranational identity.

The empirical results from a multi-year research programme (de Rosa 2013b) have widely shown the relevant relationships between the place identity anchored to different phases of the life cycle from childhood to adulthood and the varied social representations of places for people belonging to different cultures, even comparing place identity and "imagined" and "experienced" social representations of places of European capitals and of the "ideal city" in the first visitors from different nationalities (de Rosa 2013b; de Rosa and Bocci 2014, 2015, 2019a; de Rosa and Dryjanska 2014, 2017; de Rosa et al. 2017, 2019a, b).

On the basis of Proshansky's classical work, the sociocultural determinants of the structuring of place identity are expressed both in the form of fundamental "uniformity", which derives from belonging to a certain culture, and as "differentiation" within the same culture between individuals belonging to different social groups or between citizens belonging to different cultures:

Meanings of spaces and places are not universally shared [...] Attached to the physical settings that substantively define place-identity are not only the general 
social proprieties that come from the broad uniformities in a culture, but also those that serve to distinguish different groups in the culture: racial, ethnic, social, national and religious groups in a given culture should reveal not only different use and experience with space and place, but corresponding variations in the social values, meanings and ideas which underlie the use of those spaces (Proshansky et al. 1983: pp. 63-64).

If, in ordinary times, the social representations of the places and the related place identity and place attachment may be consistent or varied according to individual and cultural differences and over the length of the life cycle or in different historical times, one of the questions concerns the way in which the Covid-19 pandemic, during its different phases (from the zero phase to the post-Covid era), has affected and will affect the social representations of the multiple system of places and their experience. Research-based reflections are needed to investigate the effects of the lockdown on place identity and attachment according to the multi-faceted categorization of unnamed and named places (de Rosa 2013b):

- Home (e.g. own home, relative's home, others' home)

- Urban open places (e.g. roads, squares, streets, neighbourhoods)

- Geographical places (e.g. cities, countries, nations)

- Natural places (e.g. parks, riverside, lakes, beaches, mountains)

- Artistic-architectural places (e.g. monuments, works of art, museums)

- Institutional places (e.g. settings for work, schools, hospitals)

- Socio-recreational places (e.g. discotheques, bars, cinemas, theatres, stadiums)

- Functional places for transportation (e.g. airports, bus, metro, or railway stations) or commerce (e.g. shops, shopping centres, large retail outlets)

For each of these main categories of places, it is possible to ask specific questions.

\section{Open and closed spaces}

Due its centrality in the "place identity and place attachment", it is important to start for example by asking whether and how "home" has changed during the lockdown-as an anti-Covid-19 prevention measure-from a private family space to a multi-tasking context including a work setting. Home is a meaningful place emotionally beyond the "house" as a built space, consistently identified in the literature as the core of place identity and the most significant place over the whole life cycle (despite the new places experienced as settings of multiple activities during the various life phases and its historical transformation as a place of co-habitation of the multi-generational extended family in the past or of the nuclear family and even of singles in recent times) (de Rosa 2013b). According to Guya Bertelli, Professor of Architectural and Urban Planning at the Polytechnic of Milan, who contributed to the inquiry "The houses and the city at the time of coronavirus", an initiative of the Giornale dell'Architettura:

Especially in the public and social housing sector, a wider reflection is needed. Being the public space indispensable to recognise itself as part of the community, its dissolution within the domestic space entails a disruption of the internal/external relationship, putting a strain on not only the personal identity, but also that of the home, which assumes forms of hybridization, sometimes very evident: in fact, the domestic space becomes the seat of a series of activities that interfere in a succession of often overlapping or conflicting actions.

In this context we must pay attention to the conditions of the most disadvantaged social classes. They are the ones who have experienced (and suffered) with greater intensity, in recent months, small and inflexible internal spaces or the lack of usable open spaces, as well as inefficient telematic connections or a shortage of computer terminals. Protected open spaces and safe residential spaces are the objective that our society must set in order to make the home a renewed factor of social quality. ${ }^{12}$

The transformation of "home" into a "plural place" in the time of coronavirus has involved the "privatization of the public sphere" and the "making public of the private sphere", with public eyes entering the intimate space through virtual meetings for school, work, and social activities transferred to the private setting. The conversion to smart working of many jobs and activities (including shopping online even for ordinary food) may have long-term effects on the redefinition of the use of public and private spaces by changing the urban assets and planning and influencing the economy (with a great impulse from the digital and green healthy economy) and lifestyles (for example reducing the need for transportation and allowing people to stay at home more than travelling to an office or to live more regularly in second houses that were used for holidays before the pandemic).

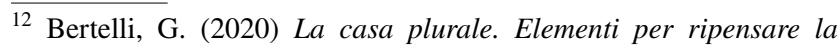
dimensione residenziale urbana e per impostare adeguate politiche dell'abitare; https://inchieste.ilgiornaledellarchitettura.com/la-casaplurale, accessed 27 June 2020.
} 
Home has been largely experienced during the lockdown as the intensification of forced social coexistence in private space in contrast to the empty public spaces in the cities, inverting the familiar dimensions of "full-empty", "crowded-isolated", and "noisy-silent" spaces. Depending on personal attitudes, the forced lockdown has been, for some people, who are inclined to engage in introspective reflections, a rare opportunity to be in contact with the inner world and to retrieve personal and family memories, even by rediscovering the usually ignored familiar objects speaking from the walls with the new perception of time, as the days turn into weeks and then into months during the pandemic.

For other people, the invitation "let's stay at home" during the quarantine became "stay at home", an obligation imposed from above, leading them to perceive their house as a prison, in some cases also depending on the quality of the relationships among the family members.

The house is a polysemic symbol, not for everyone it represents the same thing. In our family culture, however, it is the place of choice for the private, for intimacy and for protection. An "inside" that protects you from the dangers of the "outside" of the street. It is in this light that domestic violence seems so terrifying to us. The same place where you should feel safe and protected from danger becomes the site of violence. This reading indicates the ways in which we invest the contexts of socially shared meanings, forgetting that no context can exist outside the relationships we build. The quality of the relationship with our home, then, tells us about the quality of the relationships we have and how we represent them. ${ }^{13}$

The contrast between "open" and "closed" spaces during the lockdown has also contributed to different perceived experiences of home, which are also dependent on whether the house has balconies or terraces. These open spaces have become vital places to be in contact both with the outdoor natural environment (perceiving fresh air, wind, sunshine, sunset, the singing of birds, flower smells, etc.) and with neighbours (singing together, telling stories and sharing experiences, even showing national flags, united in the name of people's own nation as they wish for recovery, sharing dinners in wider spaces to respect distancing, etc.). One of the effects of the lockdown has been the re-evaluation of open spaces at home, even transforming the flat tops of buildings (previously not habitable) into furnished terraces or green areas appointed as new social wide spaces.

\footnotetext{
${ }^{13}$ Ordine degli Psicologi del Lazio (2020) 'Inside House', Festival Psicologia, https://festivalpsicologia.it/argomenti/inside-house-casarelazioni, accessed 23 June 2020.
}

A related effect has been the economic valorization in the real estate market of houses with balconies and terraces and the parallel devalorization of houses without open spaces. ${ }^{14}$

Thinking of public places, other effects experienced during the coronavirus pandemic and in some cases with a longterm influence are connected to the "virtualization of the places for social use", as institutional places not only for the enhancement of smart working or distant training activities but also for many socio-recreational and cultural activities (e.g. virtual tours of museums from home, cinema at home, theatre at home, concerts at home, ${ }^{15}$ virtual travelling, and virtual group biking).

At the moment, we do not know how long the association of crowding with the perception of potential contagion will persist in the collective memory of coronavirus by continuing new habits in people's lifestyle and social life, although the history of pandemics informs us about powerful mass oblivion as a defence mechanism (Lima and Sobral 2020). The impetus for regaining a social life as experienced for decades and even generations will most likely take over again soon. It is certain, however, at the time of the reopening of inter-regional mobility within countries and of the frontiers for international travel, tourism has recorded a gigantic crisis in the presence of foreigners and of citizens of the same nation in places far from home, other than second houses, with the renunciation of travel to exotic destinations not only due to economic problems. The current trend is a preference for farmhouses and isolated places that, being in contact with nature, are perceived as safer and healthier: "safe and clean" is the most used combination (not only to advertise holidays) according to an analysis of marketing communication in the Covid-19 era (de Rosa et al. 2021).

\section{Places and non-places}

In term of public spaces, we do not know whether the post-pandemic crisis will, for example, continue to result in reduced use of air transport, a preference for individual transportation at least in urban contexts and for bikes and scooters for shorter distances, and the avoidance of crowded

\footnotetext{
14 Semi, G. (2020) La casa che verrà. Scenari immobiliari e sistemi valoriali dell'ambito domestico visti da un sociologo "sul pezzo" Il Giornale dell'Architettura, https://inchieste.ilgiornaledellarchit ettura.com/la-casa-che-verra/ accessed 21 June 2020. Ordine degli Psicologi del Lazio, La casa che verrà: dimensioni strutturali ed emotive dell'abitare dopo la pandemia, Festival psicologia, Newsletter Festival Psicologia, 1 June 2020.

15 By naming Pandemiorkestra, an international virtual orchestra was born in Italy during the "lockdown" and "distancing" phase from an idea by Giovanni Chiapparino (Apulian musician and composer) bringing together composers and musicians from all over the world http://digressionemusic.it/pandemiorkestra/, accessed 13 May 2020.
} 
functional places for transportation (e.g. airports and bus, metro, or railway stations) or commerce (such as big shopping centres and large retail outlets). These are the places named "non-places" by Marc Augé (1995), who coined this neologism to refer to anthropological spaces of transience where human beings remain anonymous and that do not hold enough significance to be regarded as "places". In his reflection about the "anthropology of super-modernity", the concept of "non-places" opposed the notion of "anthropological places", meaning spaces that empower people's identity, where they can meet other group members with whom they share social references. According to Augé, "non-places", on the contrary, are not meeting spaces and do not build common references to a group, being places where the individual remains anonymous and lonely. It is a fact that, since the publication of his book (1985), people have assumed a diffused habit of using big shopping centres and malls not only for shopping (one of the drivers of the large trans-continental shopping tourism) but also to meet friends, even on Sundays or religious holidays, largely replacing among new generations the social gathering at ritualistic sacral places, like churches. However, this meeting function has surely not transformed a big shopping centre into a place animated by the genius loci or anima loci (Hilman 2004) in the sense of its uniqueness and beauty (as we can recognize for places like the Fontana di Trevi or Piazza di Spagna in Rome, just to mention two squares surrounded by small shops but with a unique evocative fashion). "Non-places" share many characteristics: big multi-storey escalators, large furnished spaces in front of shops to try to keep buyers there as long as possible, attracting them with socio-recreational furnished playing places for children, coffee shops, fast-food points with free wi-fi facilities, and so on. If not only for their uniformity from the functional and architectural points of view, one of the many features of "non-places" should indeed be recognized in their commercial standardization of internationally recognized brand chains (at different levels: top and medium brands to attract different categories of buyers), which makes these places ("non-places") similar in any part of the world, contrary to the genuine handcraft conception of small shops that may be found only in a specific village. Will the new touristic trend lead to the rediscovery of what in Italy is called the "Italy minor" of villages and itineraries that are usually forgotten in the modern re-edition of the classical Italian tour, quickly jumping in two to three days from Venice to Florence, Rome, and Naples? Will people (citizens and tourists) rediscover the uniqueness of authentic artisan products, sometimes having the luck to meet artisans who are more intent on the creation of a new piece than on the buyer, forgetting the big outlets where they can buy the same product in any shop centre in the world?

\section{"Visible" cities}

We should hope that the collective memory-even in the post-pandemic era-will preserve some emotional impact of the effect that the "invisible other" coronavirus had in "making the cities visible", emphasizing their architectural beauty as a silent, empty, sacral theatre as well as being conquered as a territory by birds and animals that had disappeared from the polluted urban landscape.

An interesting research question could arise to investigate empirically whether, to what extent, and for whom Rome or Paris, seen from the ground and from the sky in ordinary times (de Rosa and Bocci 2018, 2019b), has been experienced as an empty city closer to the social representations of the "ideal city" in the Covid-19 pandemic, depending on the emphasis on semantic contrasted dimensions: empty versus full, quiet versus loud, architectural-monumental beauty as place protagonist versus crowded social life as place protagonist, urban societal built environment opposed to nature versus a societal context of integrated urban/natural environment, air pollution versus air purity, and so on. ${ }^{16}$

Surely, during the pandemic lockdown, everybody was impressed by the empty places for symbolic religious ceremonies, like Saint Peter's Square in Rome (usually crowded), with Pope Francis alone on Palm Sunday, 5 April (Fig. 6) ${ }^{17}$ by the deserted Piazza Venezia in Rome during the celebratory political rite for national identity on 25 April (Festa della Liberazione), with the Italian President Sergio Mattarella alone without an escort and wearing a mask, offering homage to the dead soldiers at the Altare della Patria (Fig. 7); ${ }^{18}$ or by the virtual concert for the national holiday on 1 May offered by Gianna Nannini, who played and sang alone on a terrace with Milan Cathedral in the background (Fig. 8). ${ }^{19}$

\footnotetext{
$\overline{16}$ Among many sources, see Agostini, M. (2020) Video Roma ai tempi del coronavirus, ecco le immagini della città deserta, Agenzia Dire (Le 5 news delle 5): https://www.dire.it/28-04-2020/45325 3-video-roma-ai-tempi-del-coronavirus-le-immagini-della-citta-deser ta/ also including: VIDEO I Coronavirus, in volo su Roma con la Polizia: controlli anti-assembramenti dai cieli: https://www.dire.it/2404-2020/452013-video-coronavirus-in-volo-su-roma-con-la-poliziacontrolli-anti-assembramenti-dai-cieli/, accessed 4 April 2020.

17 Source: https://www.ilcaffe.tv/articolo/65400/nessuno-si-salva -da-solo-l-immagine-storica-del-papa-e-la-preghiera-per-tutti.

18 Source: https://www.liberoquotidiano.it/news/politica/22268388/ sergio_mattarella_papa_francesco_25_aprile_discorso_senza_scort a_altare_patria.html.

19 Source: https://tv.fanpage.it/il-primo-maggio-2020-non-potev a-essere-meglio-di-cosi/.
} 
Fig. 6 Pope Francis alone in Saint Peter's Square on Palm Sunday, 5 April

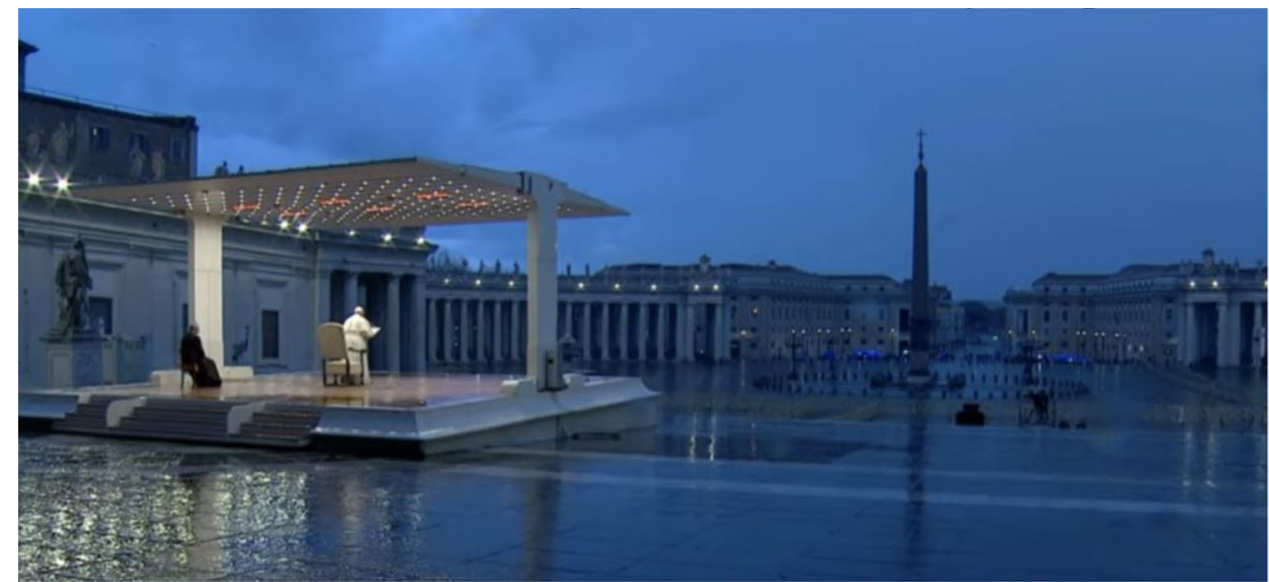

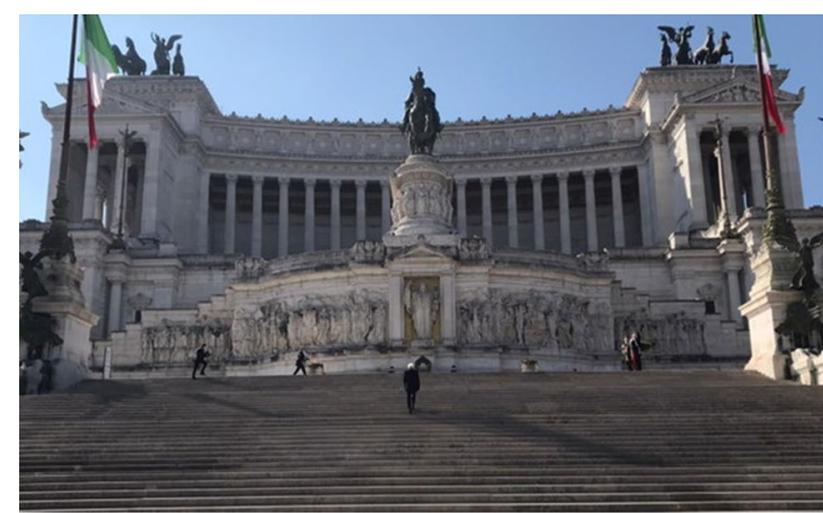

Fig. 7 The Italian President Sergio Mattarella without an escort on 25 April, Liberation Day

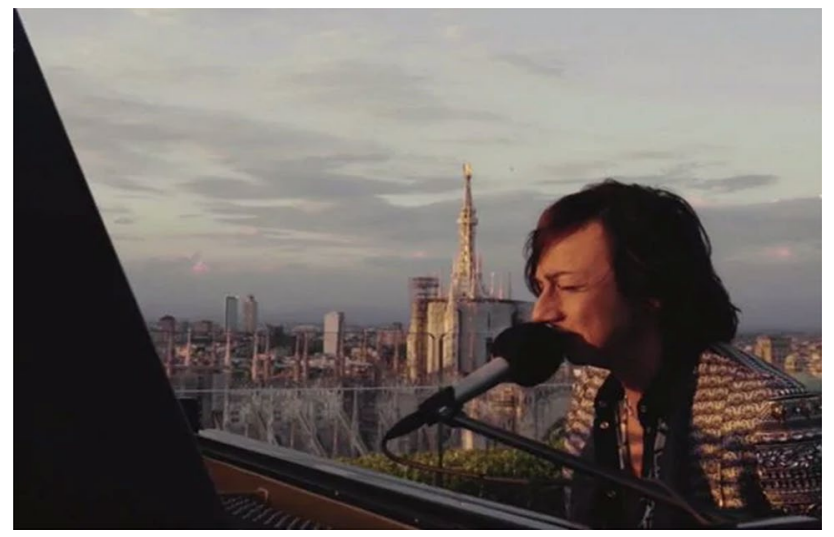

Fig. 8 Virtual concert on 1 May: Gianna Nannini playing and singing alone on a terrace with Milan Cathedral in the background

\section{The contribution of social sciences to policy making: Covid-19 as a global disaster and an opportunity}

As anticipated when beginning this article, we have documented how both the city spaces and the individual-interpersonal spaces and distances have been transformed over the few months of lockdown, highlighting the symbolic meanings of place and their intimate relationship with people's social and emotional life. We have also documented how issues of contamination, invasion, and dematerialization of relational spaces have been brought to the fore by the pandemic scenario.

From this brief overview, one major recommendation for policy makers and institutional communication can be made as far as the spatial theme is concerned: the reframing of "social distancing" as "spatial distancing" or "physical distancing" (Bonell et al. 2020; Greenaway et al. 2020).

We suggest that spatial distancing should be the term used when distance between individuals or objects is addressed. Grounded in biological and epidemiological data, spatial distance means physical extent: $2 \mathrm{~m}$. Shared responsibilities inhering in people's social and cultural contexts afford social closeness. Public health should approach the threat of COVID-19 by promoting spatial distance together with social closeness (Abel and McQueen 2020).

Use of the term "social distancing" might imply that one needs to cut off meaningful interactions. A preferable term is "physical distancing", because it allows for the fact that social connection is possible even when people are physically separated (Van Bavel et al. 2020).

In support of this claim, we put forward three arguments: $\mathrm{cul}$ ture, well-being, and resilience. The culture argument calls 
into play the distinction between individualistic and collectivistic cultures (Triandis 1995), which partially overlap with Hall's (1966) contact and non-contact cultures. Indeed, both the self-other relationship and the use of space are culturally regulated. In less individualistic societies, in which the sense of self is tightly entangled with group membership and in which people are used to turning to each other for help (even more so in times of crisis), "social distancing" may be perceived as a very disruptive message (Abel and McQueen 2020) and its consequences may be more difficult for people to endure. Along with the examination of the contextual factors that increase the vulnerability of populations and countries (economic conditions, infrastructures, health systems, etc.), cultural specificities suggest that different actions and communications might be required to contain the outbreak.

Social scientists and psychologists have loudly voiced the well-being argument that it is not only possible but also strongly recommended to maintain social connections even when people are physically distant. As Stanford psychologist Jamil Zaki put it, "social distancing was the wrong term to begin with. We should think of this time as physical distancing to emphasize that we can remain socially connected even while being apart". ${ }^{20}$ It is not just a matter of names, as there is a remarkable difference between being lonely and being isolated: while loneliness - that is, the subjective state deriving from feeling a lack of social interaction-is associated with emotional distress, isolation-that is, the objective lack of interactions - does not necessarily come with psychic affliction. We can feel lonely when we are physically with other people, and we can feel connected when lacking physical contact. "Social distancing" is therefore misleading as it conveys the message that people not only need to isolate to slow down the contagion but also to give up meaningful relationships (van Bavel et al. 2020).

However, if this were the case, a huge public health problem would immediately surface as, especially in times of crisis and emergency, people look for support and solace from others, especially those whom they care for: asking people to be deprived of social connections is at odds with the basic human need for socialization, and it has detrimental effects on physical and mental well-being. Moreover, "social distancing" conveys the notion that public health is addressed exclusively by medical measures, while there is long-standing evidence that social support and connectedness (and the lack thereof) greatly influence individual health and well-being (Taylor 2011), even when they are provided through online networks and social media (such as Facebook; see Gilmour et al. 2019). Not by chance, for many people, online interactions have made up for isolation and support has been exchanged in the virtual space. Individuals and groups who were least familiar

20 Source: Stanford News (19 March 2020)—https://news.stanford. edu/2020/03/19/try-distant-socializing-instead/. with technology, or who could not afford it, were also the most vulnerable to the damage caused by the pandemic crisis.

Finally, the resilience argument relies on disaster research, which shows that, in a great number of cases, a sense of community emerging from the awareness of being part of a "community of fate" and the emergence of shared identities set the conditions for collective resilient responses (Drury et al. 2019; Jetten et al. 2020). In a pandemic situation, social embeddedness is not only the key to coping with individual psychological stress but also spreads social norms and behaviours that can be functional in the containment of the outbreak. Only if a sense of connectedness is maintained, or even better strengthened, can communities face collective emergencies in a proactive way.

Indeed, the communal dimension has come to the forefront of all the effective pandemic responses. If, on the one hand, the new virus has disrupted and changed our everyday life, on the other hand, it has the potential to serve as a "semiotic vaccine" and to open the way "to a semiotic re-appropriation of the collective dimensions of our experience" (Venuleo et al. 2020). The European Federation of Psychologists' Associations (EFPA), along with its associate member the European Community Psychology Association (ECPA), made some key points in its Coronavirus Statement (18 May 2020) to promote concrete actions regarding "how to strengthen communities in times of crisis". These key points are inspired by the vision that

... in one of the most disruptive times in our societies there is no doubt that our "sense of community" and our ability for mutual support may become a crucial factor in how we will cope with a situation we never experienced before. This will be especially true for the weakest groups in our communities. But, in order to establish mutual support for the most vulnerable groups, one needs to maintain and nourish strong communities and a common sense of community. ${ }^{21}$

For all these reasons, health and political authorities should make it clear that they are asking for spatial distancing $\left(1 \mathrm{~m}, 2 \mathrm{~m}\right.$, or even more away from each other in public, ${ }^{22}$

\footnotetext{
${ }^{21}$ European Federation of Psychologist's Associations (EFPA) How to strengthen communities in times of crisis_EFPA position statement, from: https://www.efpa.eu/news/how-to-strengthen-communitie s-in-times-of-crisis_efpa-position-statement, accessed 20 May 2020.

22 This distance of $2 \mathrm{~m}$ has been even subject to some variable political geometry becoming one metre or even four depending on the political incoherent decisions over the time taken by the same government or by different authorities in various countries as effect of divisive attitudes towards the same fatal virus influenced by partisan voting patterns and of the conflict management between priority focused on health or economy pushed by different social actors (scientists, industrial entrepreneurs, little traders, Trade federations, trade unions, etc.): see for examples—among many other settings of application, like factories, schools, restaurants, cinema, sport fields, etc. - the polemical representations about the spatial distancing meas-
} 
depending on the settings) while promoting social connectedness. ${ }^{23}$ Institutions imposing "social" instead of "physical" distancing are paradoxically creating the conditions for risky behaviours, albeit involuntarily. This may happen because, as proved by decades of research based on social identity and self-categorization theory (Tajfel and Turner 1979; Turner et al. 1987, 1994), we trust those whom we perceive to be part of our groups more and all the others less, and precautions as well as risky behaviours are affected by our group memberships. Despite the evidence that we are more likely to be infected by those to whom we are physically close, people tend to respect social distancing more when they are with strangers and people perceived as "different" than when they are with their loved ones or their friends. As exemplified by Cruwys (2020, p. 72), in Australia, "while an impressive $84 \%$ of people avoided strangers on public transport, only $54 \%$ of people avoided colleagues or their workplace. A mere $13 \%$ of people reduced physical contact with those in their home".

Driven by the need to reshape the environment to ensure both health protection and social connectedness, urban planners-in cross- and trans-disciplinary collaborations with scientists as well as environmental, social science, and art scholars and enlightened policy makers-may find in the Covid-19 emergency an occasion to envision a postCovid-19 era in which urban, metropolitan, and megalopolis cities are transformed from complex systems of "places of fear to a community of joy" (Flick 2019), reshaping spaces as places for social "coexistence" and not only for "survival".

The search for new "coexistence" forms should overcome the traditional opposition between nature and society in a triadic relationship between society (culture, including all the expression of arts), nature, and science, as in Moscovici's wishful thinking (1968a, b, 1972/1994, 1974, 1990, 2002a, b; Moscovici and Hess 2002), anticipating Pope Francis's vision of the "common house" that inspired the Encyclical

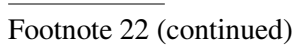

ures to be adopted on the re-opening of the beaches: DiRE by Elisa Manacorda (28 April 2020) Coronavirus balneari numero chiuso $e$ distanza ma tocca ai clienti autoregolamentarsi; https://www.dire. it/28-04-2020/453458-video-coronavirus-balneari-numero-chiuso-edistanza-ma-tocca-ai-clienti-autoregolamentarsi/; Il Fatto Quotidiano by Luisiana Gaito (12 May 2020) Ombrelloni a 5 metri, prenotazione obbligatoria e regole ferree anche per spiagge libere. Balneari: "Distanze inapplicabili, rischio chiusura"; https://www.ilfattoquotidia no.it/2020/05/12/ombrelloni-a-5-metri-prenotazione-obbligatoria-eregole-ferree-anche-per-spiagge-libere-balneari-distanze-inapplicab ili-rischio-chiusura/5799253/.

23 BBC by Gaia Vince (6 May 2020) Why it's so hard to be rational about Covid-19; https://www.bbc.com/future/article/20200505-whyits-so-hard-to-be-rational-about-covid-19; accessed 9 May 2020. BBC by Martha Henriques (6 April 2020), Social Distancing: How to persuade others it works; https://www.bbc.com/future/article/20200 402-covid-19-how-to-convince-others-social-distancing-works, accessed 8 April 2020.
Laudatio Si' (2015). ${ }^{24}$ On the other side of the Atlantic, among many leading intellectuals, Noam Chomsky's critical voice-nourished by long life experience-contextualized the current Covid-19 pandemic crisis in the wider scenario of societal, political, and environmental problems on the global scale. ${ }^{25}$

Having rapidly dismantled the perception of a sort of scientific, technological, and economic omnipotence, exposing our humanity to a forgotten vulnerability, accustomed for centuries to an increasingly intrusive dominion of nature (de Rosa and Mannarini 2020), the pandemic is thus an opportunity

a. to invent a new equilibrium in urban forms of social coexistence (density, connectivity, accessibility, etc.);

b. to reduce pollution through green transportation and industrial systems in respect of the natural environment;

c. to protect the beauty and healthy dimensions of our cities and their historical centres, admired in their absolute aesthetic purity of anima loci thanks to the salience of the architectural-artistic features in the never-beforeexperienced empty spaces during the lockdown period due to the pandemic;

d. to redesign houses with open and green spaces even in urban contexts;

e. to rethink a new equilibrium in the designs of spaces and settings, reflecting on physical, psychological, and social healthy lifestyles (including learning the "praise of slowness" from neuroscientists ${ }^{26}$ ), on our interconnected pro-

\footnotetext{
${ }^{24}$ Pope Francis (24 May, 2015) Encyclical Letter Laudatio SI' of the Holy Father Francis "On care for our common home" http://www. vatican.va/content/francesco/en/encyclicals/documents/papa-franc esco_20150524_enciclica-laudato-si.html.

25 In the interview posted online on 28 March 2002, the 91-yearold Noam Chomsky responded deeply to probing questions from his interviewer, 37-year-old Croatian political philosopher, author, and progressive activist Srecko Horvat. Noam Chomsky contextualizes the current Covid-19 pandemic crisis, which he takes seriously, in relation to the even greater, imminent threats of ecological catastrophe, growing risk of thermonuclear war, neoliberal economic policies dating back to original theorists in 1920s Vienna who welcome fascism and oppressive state violence, the US bullying imposition of murderous economic sanctions on Iran and potentially elsewhere, authoritarian political regimes, the dangers from the current US presidency, and the increasing social isolation, especially among the young, in this age of social media preoccupation. At the same time, he sees a potentially more hopeful alternative for humanity if a mass movement of people worldwide awaken and bring about truly democratic transformations in the service of all life. https://www.youtu be.com/watch? $\mathrm{v}=\mathrm{t}-\mathrm{N} 3 \operatorname{In} 2 \mathrm{rLI} 4$, accessed on 30 March 2020.

${ }^{26}$ Exemplary is the book "Elogio della lentezza" (Praise of slowness (2014) of Lamberto Maffei (former director of the Institute of Neuroscience of the CNR (National Centre of Research) and of the Laboratory of Neurobiology of the Scuola Normale di Pisa and President of the Accademia Nazionale dei Lincei). Nourished by the reflections of
} 
duction system at the local, national, and international levels, on the consequences of the impetus for the virtualization of work activities, and on the interdependence of the neighbourhood community and international human, knowledge, and technological resources in the interconnected globalized scenario and local cultures.

Whatever may happen in the future, the lesson learned from the Covid-19 pandemic is that community and shared social identities are pivotal vectors of resilience. All interventions, at the psychological, social, environmental, political, and spatial levels, that aim to promote such dimensions in everyday life and settings, in urban as well as in rural areas and across places, groups, and cultures, contribute to strengthening the fundamental societal ability to cope with threats and unpredictable disruptive events (Jodelet et al. 2020).

Acknowledgements The image presented in Fig. 4-a lady embracing a monument as an expression of love-is reproduced with kind permission of H. Walton/T.G. Townshend (Source: Townshend, in press).

\section{References}

Abel, T., and D. McQueen. 2020. The Covid-19 pandemic call for spatial distancing and social closeness: Not for social distancing. International Journal of Public Health. https://doi.org/10.1007/ s00038-020-01366-7.

Abric, J.C. 1996. Papers on social representations, 5(1), 77-80. https ://www.researchgate.net/publication/284667199_Specific_Proce sses_of_Social_Representations. Accessed 23 June 2020.

Akerlof, G.A. 1997. Social distance and social decisions. Econometrica 65: 1005-1027.

Allcott, H., L. Boxell, J.C. Conway, M. Gentzkow, M. Thaler, and D.Y. Yang. 2020. Polarization and public health: Partisan differences in social distancing during the coronavirus pandemic. https://doi. org/10.2139/ssrn.3570274

Ardrey, R. 1996. The territorial imperative: A personal inquiry into the animal origins of property and nations. New York: Atheneum.

Augé, M. 1995. Non-places: An introduction to anthropology of supermodernity, New York-London: Verso ed. or. Non-Lieux, Introduction à une anthropologie de Ia surmodernité. Paris: Seuil.

Bentley, S. V., T. Cruwys, J. Jetten, C.R. Crimston, and H.P. Selvanathan. 2020. In Isolated in isolation: The negative impact of social distancing for those already disconnected, ed. J. Jetten, S.D. Reicher, A.S. Haslam, and T. Cruwys. Unpublished manuscript: The University of Queensland.

\section{Footnote 26 (continued)}

well-known intellectuals such as Roland Barthes, Zygmunt Baumann, Italo Calvino, David Kahneman, Milan Kundera, the book is an invitation to explore the brain mechanisms that guide the rapid reactions of human organism, of both genetic and cultural origin, to discover the advantages of a civilization dedicated to thoughtfulness and slow thinking, "We live in a fast world, where time seems to gradually contract: constantly connected, called to respond quickly to e-mails, tweets and sms, hyper-tickled by the images, in a visual frenzy and cognitive with pathological traits. So we forget that the brain is a slow machine and, in an attempt to imitate fast machines, we encounter frustrations and worries".
Bogardus, E.S. 1933. A social distance scale. Sociology and Social Research 17: 265-271.

Bonell, C., S. Michie, S. Reicher, R. West, L. Bear, L. Yardley, V. Curtis, R. Amlôt, and G.J. Rubin. 2020. Harnessing behavioural science in public health campaigns to maintain 'social distancing' in response to the COVID-19 pandemic: Key principles. Journal of Epidemiology and Community Health. https://doi. org/10.1136/jech-2020-214290.

Cruwys, T. 2020. Risk perception. In Together apart. The psychology of Covid-19, Social Science Space, ed. J. Jetten, S.D. Reicher, A.S. Haslam, and T. Cruwys, 68-72. London: Sage.

de Rosa, A.S. 1987. The social representations of mental illness in children and adults. In Current issues in European Social Psychology, ed. W. Doise and S. Moscovici, vol. 2, 47-138. Cambridge: Cambridge University Press. [ISBN: 05-21-32-71-99].

de Rosa, A.S. (ed.). 1995. Se per la strada incontri un matto ... Sviluppo dei sistemi di credenze e risposta sociale alla devianza in bambini e adolescenti, Roma: Melusina Editrice, 483. [ISBN: 88-7697-027-4].

de Rosa, A.S. 2009. Mito, ciência e representações sociais. In Pensamento Mítico e Representações Sociais, Coleção Educação e Psicologia, ed. E. Coelho Paredes, and D. Jodelet, vol.13, 123-175. EdUFMT/FAPEMAT/edIUNI: Coxipó Cuiabá [ISBN: 978-85-327-0319-4].

de Rosa, A.S. 2010. Mythe, science et représentations sociales. In Pensée mytique et représentations sociales, ed. D. Jodelet and E. Coelho Paredes, 85-124. L'Harmattan, Paris. (ISBN 978-2-296-12324-3).

de Rosa, A.S. 2013a. Taking stock: a theory with more than half a century of history. In Social Representations in the "social arena", ed. A.S. de Rosa, 1-63. London: Routledge.

de Rosa, A.S. 2013b. Place-identity and social representations of historic capital cities: Rome through the eyes of first-visitors from six countries. In Social Representations in the "social arena," ed. A.S. de Rosa, 311-381. London: Routledge.

de Rosa, A.S. 2014. The role of the Iconic-Imaginary dimensions in the modelling approach to social representations. In Special issue on social imaginaries, papers on social representations, ed. A. Arruda, M.A. Banchs, M. De Alba, and R. Permandeli. 23, 17.1-17.27. ISSN 1819-3978. http://www.psych.lse.ac.uk/psr/.

de Rosa, A.S. 2016. Mise en réseau scientifique et cartographie de la dissémination de la théorie des représentations sociales et son impact à l'ère de la culture bibliométrique. In Les représentations sociales, ed. G. Lo Monaco, S. Delouvée, and P. Rateaux, 51-68. Brussels: Editions de Boeck.

de Rosa, A.S. 2019. For a biography of a theory. In Serge Moscovici. Un regards sur les mondes communs, ed. N. Kalampalikis, D. Jodelet, M., Wieviorka, D. Moscovici, and P. Moscovici, 155-165. Paris, Editions de la Maison des sciences de l'homme (collection "54").

de Rosa, A.S. and M.N. Schurmans. 1990. Madness imagery across two countries. Rassegna di Psicologia, 3, 177-193. [ISSN: 1125-5196 E141492].

de Rosa, A.S., and E. Bocci. 2013. Resisting cognitive polyphasia in the social representations of madness. In Social representations in the "social arena", ed. A.S. de Rosa, 245-310. London: Routledge.

de Rosa, A.S., and E. Bocci. 2014a. Place @-Branding and European Capitals:"city visiting cards" via municipal websites, virtual tours of significant places flying with Google Earth, and conversational exchanges about city-places experienced/imagined via social networks. In Dynamics of competitive advantage and consumer perception in social marketing, ed. A. Kapoor and C. Kulshrestha, 126-168. IGI Global: Hershey. https://doi. org/10.4018/978-1-4666-4430-4.ch006. 
de Rosa, A.S. and L. Dryjanska. 2014b. Place-Identity and Social Representations of Historic European Capitals: Multi-Year Field Study on First-Visitors from different Eu and non-Eu Countries. Anais da 12 a Conferência Internacional sobre Representações Sociais e IV Colóquio Luso-Brasileiro sobre Saúde, Educação e Representações Sociais, 2194-2201. São Paulo, Brazil, 20th-23th July 2014.

de Rosa, A.S. and Bocci, E. 2015. Place @-Branding and European Capitals: "City Visiting Cards" via Municipal Websites, Virtual Tours of Significant Places Flying with Google Earth, and Conversational Exchanges about City-Places Experienced/ Imagined via Social Networks. In Information Resources Management Association ed. Hospitality, travel and tourism: Concepts, methodologies, tools and applications, 314-345. IGI Global: Hershey.

de Rosa, A.S., and L. Dryjanska. 2017. Evaluative dimensions of urban tourism in capital cities by first-time visitors. In Encyclopedia of Information Science and Technology, 4th ed., ed. M. KhosrowPour, 4064-4076. Hershey: IGI Global.

de Rosa, A.S., and E. Bocci. 2018. Rome seen from the ground and from the sky, also compared to the ideal city. The social representations from the perspective of long-term residents and of airport workers. In Heritage open space in transformation. Changing attitudes, ed. D. Babalis, 54-65. Altralinea Edizioni: Firenze.

de Rosa, A.S., and E. Bocci. 2019a. The case study of Paris in an increasingly uncertain Europe. In: Proceedings of the International Conference on changing cities IV: Spatial, design, landscape and socio-economic dimensions, ed. A. Gospodini, 498-511, Chania, Crete Island, Greece June 24-29.

de Rosa, A.S., and E. Bocci. 2019b. Paris "overground" and "undergound": social representations and pracitces practices of drivers in the city, In Identidades Y Conflictos Socailes Aportes $y$ desafíos de la investigación sobre representaiociones sociales, ed. S. Seidman, and N. Pievi, 417-438. Ed. de Belgrano. Buenos Aires.

de Rosa, A.S., E. Bocci, and L. Dryjanska. 2017. Social Representations of the European Capitals and Destination@-branding via Multi-channel Web Communication. Journal of Destination Marketing \& Management. https://doi.org/10.1016/j. jdmm.2017.05.004.

de Rosa, A.S., L. Dryjanska, and E. Bocci. 2018a. The impact of the impact: meta-data mining from the SoReCom "A.S. de Rosa" @ Library. In Encyclopedia of Information Science and Technology, 4th ed., ed. M. Khosrow-Pour, 4404-4421. IGI Global: Hershey.

de Rosa, A.S., L. Dryjanska, and E. Bocci. 2018b. Mapping the dissemination of the theory of social representations via academic social networks. In Encyclopedia of Information Science and Technology, 4th ed., ed. M. Khosrow-Pour, 7044-7056. Hershey: IGI Global.

de Rosa, A.S., E. Bocci, and M. Latini. 2019a. The socio-economic dimension of ten European Capitals through the lens of destination@-branding. In Proceedings of the International Conference on Changing Cities IV: Spatial, Design, Landscape \& Socio-economic Dimensions, ed. A. Gospodini, 833-847. Chania, Crete Island, Greece June 24-29, 2019.

de Rosa, A.S., L. Dryjanska, and E. Bocci. 2019b. Evaluative dimensions of urban tourism in capital cities by first-time visitors. In Advanced methodologies and technologies in digital marketing and entrepreneurship, ed. M. Khosrow-Pour, 524-538. Hershey: IGI Global.

de Rosa, A.S., E. Bocci, M. Salvati, M. Latini, M. Bonito, N. Carpignano, A. Nubola, A., et al. 2020a. Transversal polarised discourse about "immigration" through multiple social media: Twitter, Facebook, Instagram, You Tube. In 14th annual International Technology, Education and Development,(INTED 2020), ed. L. Gómez Chova, A. López Martínez, and I. Candel Torres,
Valencia, 2nd, 3rd and 4th of March, 2020, 3257-3267. Valencia: IATED Academy.

de Rosa, A.S., E. Bocci, A. Nubola, and M. Salvati, M. 2020b. The Polarized Social Representations of 'immigration' through the photographic lens of INSTAGRAM and its impact. Psychology Hub. 3 (XXXVII): 5-22.

de Rosa, A.S. Dutto, M. Latini, and S. Taieb. 2021. Close from Afar: e-learning and resilience challenges for vulnerable communities in times of Covid-19 crisis. In 15th annual International Technology, Education and Development (INTED 2021), Valencia, 8-10 March, 2021

de Rosa, A.S., and T. Mannarini. 2020. The "invisible other": Social representations of COVID-19 pandemic in media and institutional discourse. Papers on Social Representations, Special issue on Social Representations of Covid19. 29 (1): 5.1-5.35. http:// psr.iscte-iul.pt/index.php/PSR/index

de Rosa, A.S., T. Mannarini, L. Gil de Montes, A. Holman, M.A. Lauri, L. Negura, A.I. Giacomozzi, et al. (2021). Sense making processes and social representations of COVID-19 in multivoices public discourse: illustrative examples of institutional and media communication in ten countries, Community Psychology in Global Perspective, Special Issue on "Community responses to COVID19 pandemic", 7 (1) in press

D'Urso, J. 2020. Here's why some pictures of people supposedly breaking coronavirus social distancing rules can be misleading. BuzzFeed News (April 28). https://www.buzzfeed.com/joeydurso/ coronavirus-social-distancing-lockdown-photos.

Drury, J., H. Carter, C. Cocking, E. Ntontis, S. Tekin Guven, and R. Amlôt. 2019. Facilitating collective psychosocial resilience in the public in emergencies: Twelve recommendations based on the social identity approach. Frontiers in Public Health 7: 141 https://doi.org/10.3389/fpubh.2019.00141.

Eibl-Eibesfeldt, I. 1970. Ethology. The biology of behavior. London: Holt -Rinehart and Winston.

Eibl-Eibesfeldt, I. 1989. Human ethology. New York: Aldine de Gruyter.

Emiliani, F., and A. Palmonari. 2019. Repenser la théorie des représentaions sociales. Les Editions du Net: San Ouen.

Flament, C. 1994. Structure et dynamique des représentations sociale. In Pratiques socialed et représentations, ed. J.C. Abric, 37-57. Paris: Presses Universitaires de France.

Flick, G.M. 2019. Elogio della città. Dal luogo delle paure alla comunità della gioia. Roma: Ed. Paoline.

Gilmour, J., T. Machin, C. Brownlow, and C. Jeffries. 2019. Facebookbased social support and health: A systematic review. Psychology of Popular Media Culture. https://doi.org/10.1037/ppm0000246.

Greenaway, K.H., A.K. Saeri, and T. Cruwys. 2020. Why are we calling it 'social distancing'? Right now, we need social connections more than ever. The Conversation (24 March). https://theconvers ation.com/why-are-we-calling-it-social-distancing-right-nowwe-need-social-connections-more-than-ever-134249.

Hall, E. 1966. The hidden dimension. New York: Doubleday \& Co.

Hilman, J. 2004. L'anima dei luoghi (conversazione con Carlo Truppi). Milano: Rizzoli.

Hoxter, A.L., and D. Lester. 1995. Social distance evaluations in white and African-American students. Perceptual and Motor Skills 80: 478.

Idoiaga, Mondragon N., L. Gil de Montes, and J. Valencia. 2017. Understanding Ebola outbreak: Social representations of emerging infectious diseases. Journal of Health Psychology 22: 951-960.

Jetten, J. 2020. Inequalities. In Together apart. The psychology of Covid-19, Social Science Space, ed. J. Jetten, S.D. Reicher, A.S. Haslam, and T. Cruwys, 121-126. London: Sage. 
Jodelet, D. 1989. Folies et representations sociales. Paris: Presses Universitaires de France; (1991). Madness and Social Representations, Hempstead: Harvester.

Jodelet, D. 2008. Social representations: The beautiful invention. Journal for the Theory of Social Behaviour 38: 411-430.

Jodelet, D. 2011. Dynamiques sociales et formes de la peur. Nouvelle revue de psychosociologie 2 (12): 239-256. https://doi. org/10.3917/nrp.012.0239.

Jodelet, D. 2016. La représentation: notion transversale, outil de la transdisciplinarité. Cadernos de Pesquisa 46 (162): 1258-1271.

Jodelet, D., J. Vala, and E. Drozda-Senkowska. 2020. Societies under threat. A pluri-disciplinary approach. Frontiers in Sociology and Social Research. https://doi.org/10.1007/978-3-030-39315-1_1.

Joffe, H., and G. Haarhoff. 2002. Representations of far-flung illnesses: The case of Ebola in Britain. Social Science \& Medicine 54: 955-969.

Jovchelovitch, S., and J. Priego-Hernandez. 2015. Cognitive polyphasia, knowledge encounters and public spheres. In Cambridge handbook of social representations, ed. G. Sammut, E. Andreouli, G. Gaskell, and J. Valsiner, 163-178. Cambridge: Cambridge University Press.

Kerkman, D., D. Stea, K. Norris, and J.L. Rice. 2004. Social attitudes predict biases in geographic knowledge. The Professional Geographer 26: 258-269.

Lee, S.Q., D.I. Templer, J. Mar, and M. Canfield. 2002. Social distance and trait attribution among four Southeast Asian ethnic groups in the United States. Psychological Reports 91: 326-330.

Lima, M.L., and J.M. Sobral. 2020. Threat and oblivion: interpreting the silence over the Spanish Flu (1918-19). In Societies under threat. A pluri-disciplinary approach, ed. D. Jodelet, J. Vala, and E. Drozda-Senkowska, 187-200. Switzerland: Springer. https:// doi.org/10.1007/978-3-030-39315-1_1.

Lo Monaco, G., S. Delouvée, and P. Rateaux, eds. 2016. Les représentations sociales. Brussels, Belgium: Editions de Boeck.

Lorenz, K. 1966. On aggression. New York: Harcourt, Brace and World.

Luhmann, N. 1984. Soziale Systeme. Grundrißeiner allgemeinen Theorie. Frankfurt am Main: Suhrkamp.

Lyman, S.M., and M.B. Scott. 2009. Territoriality: a neglected sociological dimension. In People and buildings, ed. R. Gutman, 65-82. New Brunswick and London: Transaction Publisher.

Maffei, L. 2014. Elogio della lentezza. Bologna: Il Mulino.

Mannarini, T., S. Salvatore, and G.A. Veltri. 2020. Identity, otherness, and psycho-cultural dynamics. In Media and social representations of otherness. Psycho-social-cultural implications, ed. T. Mannarini, S. Salvatore, and G.A. Veltri, 1-16. Cham: Springer.

Matthew, J.L., and T. Matlock. 2011. Understanding the link between spatial distance and social distance. Social Psychology 42: 185-192.

Montagu, A. 1971. Touching: The human significance of the skin, New York, NY: Columbia University Press. it. transl. Il Tatto, Milano: Garzanti.

Moscovici, S. 1961/1976. La psychanalyse son image et son public. Etude sur la répresentation sociale de la psychanalyse. Paris, France: Presses Universitaires de France. [PDF] Portuguese translation of the First Part by A. Cabral (1978), A representaçao social da psicanálise, Zahar, Rio de Janeiro; Portuguese Edition of the integral book by P. Guareschi (2011), A psicoanalise: sua imagem e seu público, Vozes, Rio de Janeiro; English edition by G. Duveen (2008), Psychoanalysis. Its Image and Its Public, Polity Press, Cambridge; Italian Edition by de Rosa, A.S. (2011). La psicoanalisi, la sua immagine, il suo pubblico Milano Edizioni Unicopli, 450.

Moscovici, S. 1968a. Pourrons-nous gouverner la nature? Entretien. Raison Présente 13: 25-36.
Moscovici, S. 1968b. Essai sur l'Histoire Humaine de la Nature. Paris: Flammarion.

Moscovici, S. 1972/1994. La Société Contre La Nature. Paris: Union géneral d'éditions, Editions du Seuil (2nd ed.).

Moscovici, S. 1974. Hommes Domestiques Hommes Sauvages. Paris: Union géneral d'éditions, Editions du Seuil (2nd ed.).

Moscovici, S. 1988. Notes towards a description of social representations. European Journal of Social Psychology 18 (3): 211-250.

Moscovici, S. 2000. Social representations: Explorations in social psychology (edited and introduced by Gerard Duveen). Cambridge: Polity Press.

Moscovici, S. 2001. Why a theory of social representations? In Representations of the social: Bridging theoretical traditions, ed. Kay Deaux and Gina Philogene, 18-61. Oxford: Blackwell.

Moscovici, S. 2002a. Réenchanter la nature. Entretiens avec Pascal Dibie. Paris: Editions de l'Aube.

Moscovici, S. 2002b. De la Nature. Pour Penser l'Écologie Paris: Métailié.

Moscovici, S., and R. Hess. 2002. Réenchanter la nature. Entretiens de Rémi Hess avec Serge Moscovici. Les Irréductibles 1: 373-384.

Ogbunu, C.B. 2020. How social distancing became social justice. Wired (18 March). www.wired.com/story/opinion-how-socia 1-distancing-became-social-justice/.

Paez, D., and J.A. Perez. 2020. Representaciones Sociales del Covid-19 International Journal of Social Psychology, Special Issue: La Psicología Social ante el COVID-19, 25: 12-21, PsyArxiv Preprints from https://psyarxiv.com/fdn32. Accessed 22 June 2020.

Phillips, T. 2020. Brazil: Bolsonaro's defiance of distancing criticized by health minister. The Guardian (13 April 2020). www.thegu ardian.com/world/2020/apr/13/brazil-bolsonaro-coronaviru s-covid-19-social-distancing.

Proshansky, H.M., A.K. Fabian, and R. Kaminoff. 1983. Place-identity: Physical world socialization of the self. Journal of Environmental Psychology 3: 57-83.

Rimé, B. 2020. Collective responses to collective traumas: synchronization and collective resilience. In Societies under threat A pluridisciplinary approach, ed. D. Jodelet, J. Vala, and E. DrozdaSenkowska, 201-212. Switzerland: Springer Nature.

Riggins, S.H. 1997. The language and politics of exclusion: Others in discourse. Thousand Oaks: Sage.

Salvatore, S. 2018. Cultural psychology as the science of sensemaking: A semiotic-cultural framework for psychology. In The Cambridge handbook of sociocultural psychology, 2nd ed., ed. A. Rosa and J. Valsiner, 35-48. Cambridge: Cambridge University Press.

Sammut, G., E. Andreouli, G. Gaskell, and J. Valsiner. 2015. The Cambridge handbook of social representations. Cambridge: Cambridge University Press.

Schumann, J. 1976. Social distance as a factor in second language acquisition. Language Learning 26: 135-143.

Shepard, C.A., H.G. Giles, and B.A. LePoire. 2001. Communication accommodation theory. In The new handbook of language and social psychology, ed. P. Robinson and H.G. Giles, 33-56. New York: Wiley.

Sitto, K., and E. Lubinga. 2020. A disease of privilege? Social Repesentations in online conversation about Covid-19 amongst some South Africans during lockdown, Papers on Social Representations, Special issue on Social Representations of Covid-19. 19, 29(2): 6.1-6.29. http://psr.iscte-iul.pt/index.php/PSR/index.

Stokols, D. 1972. On the distinction between density and crowding: Some implications for future research. Psychological Review 79: $275-278$.

Tajfel, H., and J.C. Turner. 1979. An integrative theory of intergroup conflict. In The social psychology of intergroup relations, ed. W.G. Austin and S. Worchel, 33-48. Brooks/Cole: Monterey. 
Taylor, S.E. 2011. Social support. A review. In The Oxford handbook of health psychology, ed. H.S. Friedman, 189-214. Oxford: Oxford University Press.

Townshend, T.G. in press. Healthy cities? Design for well-being. London: Lund Humphries.

Tomazin, F. 2020. 'Tsunami' of cases as coronavirus spreads where social distancing is a privilege. Sydney Morning Herald (April 4). www.smh.com.au/national/tsunami-of-cases-as-coronaviru s-spreads-where-social-distancing-is-a-privilege-20200403p54gr0.html.

Triandis, H.C. 1995. Individualism and collectivism. Boulder: Westview Press.

Turner, J.C., M.A. Hogg, P.J. Oakes, S.D. Reicher, and M.S. Wetherell. 1987. Rediscovering the social group: A self-categorization theory. Oxford: Basil Blackwell.

Turner, J.C., P.J. Oakes, S.A. Haslam, and C. McGarty. 1994. Self and collective: Cognition and social context. Personality and Social Psychology Bulletin 20: 454-463.

Valentino-De Vries, J., D. Lu, and G.J.X. Dance. 2020. Locating data says it all: Staying at home during Coronavirus is a luxury. New York Times (April 3). www.nytimes.com/interactive/2020/04/03/ us/coronavirus-stay-home-rich-poor.html.

Van Bavel, J., K. Baicker, P.S. Boggio, V. Capraro, A. Cichocka, M. Cikara, M.J. Crockett, et al. 2020. Using social and behavioural science to support COVID-19 pandemic response. Nature Human Behavior. https://doi.org/10.1038/s41562-020-0884-z.

Venuleo, C., O.C.G. Gelo, and S. Salvaltore. 2020. Fear, affective semiois and management of the pandemic crisis: Covid-19 as semiotic vaccine? Clinical Neuropsychiatry 17 (2): 117-130.

Wagoner, B. 2015. Collective remembering as process of social representations. In The Cambridge handbook of social representations, ed. G. Sammut, E. Andreouli, G. Gaskell, and I. Valsiner, 143-162. Cambridge: Cambridge University Press.

Washer, P. 2006. Representations of mad cow disease. Social Science and Medicine 62: 457-466.

Yezli, S., and A. Khan. 2020. Covid-19 social distancing in the Kingdom of Saudi Arabia: Bold measures in the face of political, economic, social and religious challenges. Travel Medicine and Infectious Disease. https://doi.org/10.1016/j.tmaid.2020.101692.

Publisher's Note Springer Nature remains neutral with regard to jurisdictional claims in published maps and institutional affiliations. 